Historic, Archive Document

Do not assume content reflects current scientific knowledge, policies, or practices. 



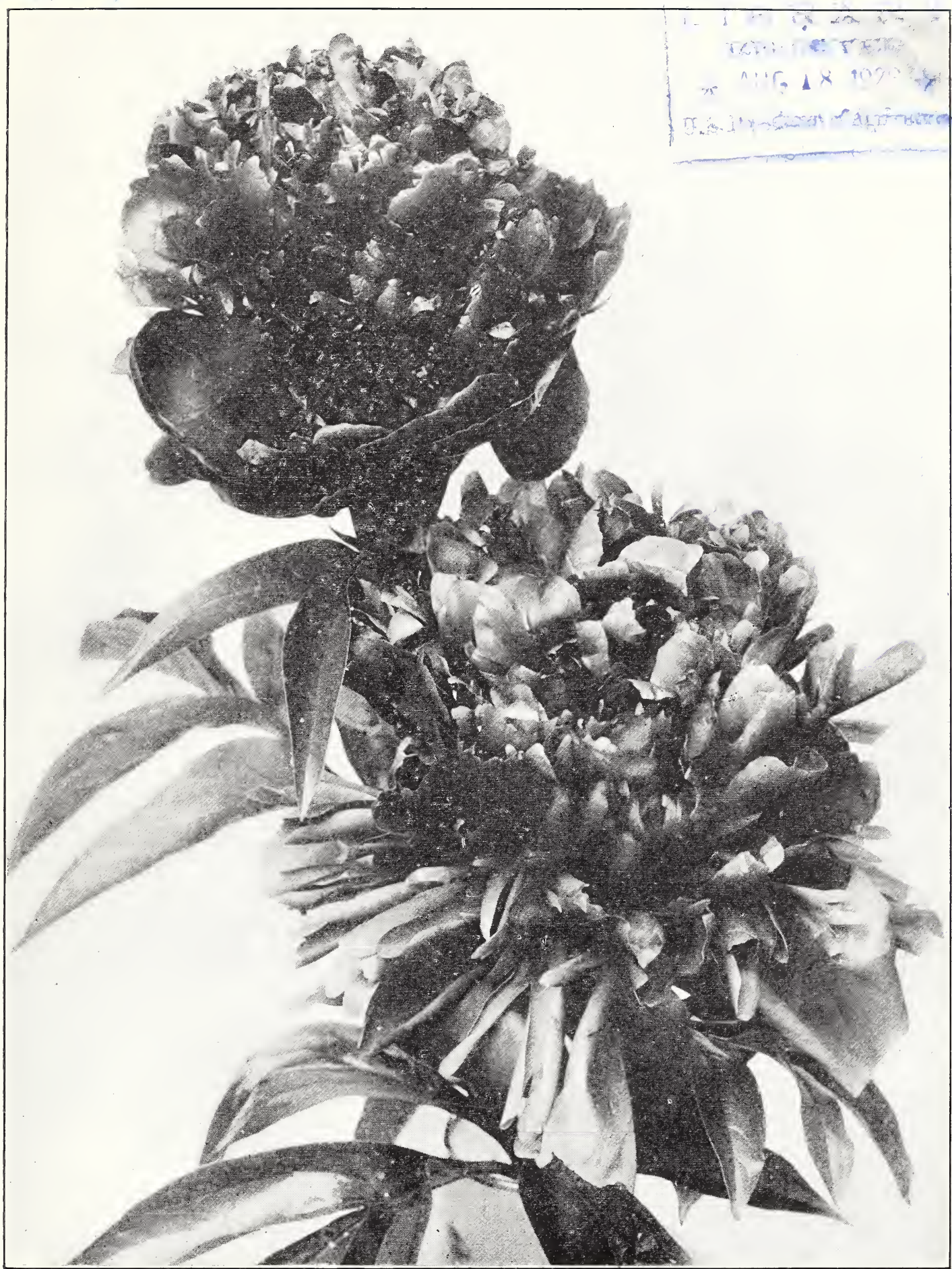

KA R L R O S E N FI E L D - TW O B E A U T I E S - M. M . C A H U Z A C (Below) (Alove)

A Message from Rosedale ROSEDALE N URSERIES (S. G. HARRIS, Prop.) TARRYTOWN, N. Y. 


\section{A MESSAGE from ROSEDALE}

As we near the end of more than three decades at Rosedale, we have a special message for our friends. We have had joy at Rosedale. The joy of growing the finest trees and flowering plants which knowledge and love combined make possible.

Joy has been ours because of the pride we have taken in the enduring friendships which have come to us. Enduring because built upon a common love for Nature's beautiful things and upon a bond of faith and trust reposed in us by those who have been our customers. Nay, not merely customers, but joint workers together in the realm of fioriculture.

AND NOW FOR THE MESSAGE. The time approaches when it is possible and perhaps even probable that ROSEDALE will pass from its present ownership. Beautiful Westchester County is being transformed by a network of splendid modern motor roads. One of these, the SAW MILI RIVER PARKWAY, will ultimately pass

\section{Through the Heart of Rosedale}

We must therefore look ahead. For the next two years we shall refrain from any expansion of our valuable holdings. We shall devote these two years to gradually disposing of our stocks of Peonies, Iris, Phlox, Roses, etc.

There can of course be no change in quality. That has been established for thirty years. Where our stocks are large,

\section{We shall Reduce Former Prices to meet the coming situation}

The discounts shown on page 5 will convince you that this is no idle message which we send you. It is a message of ROSEDALE quality at less than ROSEDALE prices.

During our thirty years at Rosedale, we have never attempted to sell the lowest priced goods. But we have attempted and we hope we have succeeded in selling the very finest quality trees and plants at prices so reasonable that many of our first customers are still with us.

We know that you have confidence in ROSEDALE products. We feel that you will be glad to avail yourself of this exceptional opportunity to secure them. While this is not in any way, shape or manner a Closing-Out Sale, it is a wonderiul opportunity for you arising from the probable interference of Westchester County Parkways with our Rosedale property. 


\section{PEONIES for FALL PLANTING}

No flowers exceed the Peonies in popularity and none are more easily grown. They are seldom attacked by insects or disease, and are perfectly hardy, requiring no covering in the severest weather. They thrive in all kinds of soil and flourish in a rich, deep loam. They demand much moisture at blooming time, and if grown in partial shade the blooms will, therefore, last longer and be equally fine in other respects.

No hardy perennial is of more permanent value than the Peony. The first cost is the only cost, and they continue to increase in size and value for many years. The foliage is rich and of beautiful deep green color, adapted for interior decoration and none make mo bed on the lawn. Their popularity has increased during the past few years site through the various shades of pink and red to the deepest purple and maroon, in a!l possible combinations of tint and form.

\section{Suitable Places for Peonies}

Since peonies are very decorative in all situations, not only because of the splendor of their blooms but also from their attractive foliage, they are not out oc place in almost any location. Care should be taken, however, not to plant them too near the spreading rosts of trees and shrubs which would rob them of nourishment and moisture, but partial shade from trees at a distance is beneficial. Peonies make a very attractive border along a path or driveway, especially if planted alternately with phlox so that the season of bloom may be continued most of the summer. They are also very effective in large beds, either alone or interspersed with phlox. If desired for abundance of cut flowers only, they may be planted in the vegetable garden.

\section{Suggestions for Peony Collections}

Peony prices vary so greatly that many purchasers believe that price depends on the quality. While this may be true to a certain extent, it is in general far from the truth. Price is regulated largely by supply and demand. If the quality is good, the demand will izcrease more rapidly in some cases than the supply, so that it will be many years before the price will be reduced to the common level. A gond sample of this is Festiva Maxima, one of the very best peonies in cultivation today and still in great demand although introFestiva Maxima, one of the very best peonies in cultivation today and still in great demand although intro-
duced seventy-four years ago. A variety equally good introduced today would be held at $\$ 100$ per root. Everybody who saw it would want it; the demand would be great and the price would drop very slowly, until the amount of stock had overtaken the demand. This would take many years as the stock of the peony increases by division only (a slow process) and the demand increases as the variety becomes better known. If on the other hand the new variety does not become popular by reason of high quality the demand will soon be overtaken by the supply and the price will rapidly drop. The price of peonies now rated at 8.5 and up, on a scale of 10 , will drop very slowly in the years to come, owing to the increasing demand. There are, however, many of the old varieties now sold at less than $\$ 1.00$ which should be in every collection. They are not all as good as Festiva Maxima, not all as well known, but they come at different collection. They are not all as good as Festiva Maxima, not all as well known, but they come at different
seasons and of different colors, in gathering together our collection of nearly 200 varieties, we have eliminated many that were unworthy. We do not believe we now have a single variety unworthy of cultivation. One's selection would depend largely on the choice of color, season of bloom and price. As to color and season of bloom, page 4 will enable one to make a sel zction to one's taste. And the price of each is given in the following pages and also in the order sheet.

We are often asked to name a few good varieties, not too expensive. For the benefit of intending purchasers we give below three lists, any of which on? might be happy to own. While these lists are made by one who has worked with peonies many years, it is not infallible and would not be agreed to by all. But we think most of the other peony specialists would agree with us. While to amateurs some of the prices in list No. 3 may seem a little high, 1 think all peony fans will agree that the prices will not be greatly reduced on the same for sometime, owing to the increasing denand, for every one of these is a gem.

List No. 1

Price.] 50c to $\$ 1$

WHITE

Alba Sulphurea

Boule de Neige

Couronne d'Or

Duchess de Nemours

Festiva Maxima

L.a Fiancee

Mme. Crousse

Mme. Crousse
Mme. de Verneville

Mme. de Verneville

Marie Lemoine PINK

Albert Crousse

Carnea Elegans

Dorchester

Edulis Superba

Gen. Bertrand

Grandiflora Nivea plen

Jeanne d'Arc

Living stone

Mme. Bollet

Mme. de Galhau

Mme. de Vatry

Marguerite Gerard

Octavie Demay

Triomphe de Lille

RED

Augustin d'Hour

Felix Crousse

De Candolle

Delachei

Prince de Talindyke

Raphael

Ville de Nancy
List No. 2

Priced \$1 to \$2

WHITE

Avalanche

Baroness Schr

Mme. Emile Lemoine

Marcelle Dessert

Marie Jacquin

Mont Blanc

Asa Gray

Germaine Bigot

Cloire de Chas. Gombault

Grandiflora

Lamartine

Mme. Emile Galle

Mme. Lemonier

Mme. Lemonier

Marie Crousse

Modeste Guerin

Mons. Jules El

Philomele

Venus

RED

Adolphe Rousseau

Eugene Bigot

Karl Rosenfield

Lord Kitchener

SINGLE AND JAPANESE

Carnot

Darkness

La Fiancee

Lemon Queen

L'Etincelante

Lucienne

The Moor

Whitleyi Major
List No. 3

Priced at $\$ 2$ or more

WHITE

Frances Willard

Kelway's Glorious

Le Cygne

Alsace Lorraine

Elwood Pleas

Eugene Verdie

Henry Avery

Jeannot

Lady Alexandra Duff

La France

Mme. Jules Dessert

Martha Bulloch

Milton Hill

Reine Hortense

Sarah Bernhardt

Solange

Therese

Tourangelle

Walter Faxon

Longfellow

Mme. Gaudichau

Mons. Martin Cahuzac

Clairette

Kino-Kimo

Le Jour

Snow Wheel

Some Ganoko

Marguerite Dessert

Mikado

Tokio

PINK 


\section{A Month of Peonies According to Color}

Let us help you select early, midseason and late varieties, so as to give a month of white, a month of yellow, a month of light pink, a month of deep pink, a month of red or a month of purple.

In the following list of Peonies according to color, we have indicated by the letter "E"-early; "M"midseason; and "L"-late varieties. These are still further differentiated,- very early, early midseason, late midseason, very late in the descriptions in the full alphabetical list.

The earliest to bloom are the Officinalis varieties, which begin blooming in this vicinitiy about May 20 th, the season closing June 25 th to July 4 th with such varieties as Grandiflora, Madame de Galhau, Madame Emile Galle, Marie Lemoine, Purpurea Superba and others.

\section{Double Varieties}

\section{WHITE}

Alba Sulphurea (M) Albatre (M)

Alsace-Lorraine (L)

Avalanche (M)

Baroness Schroeder

Boule de Neige (E)

Couronne d'Or (L)

Festiva (L)

Festiva Maxima (M)

Frances Willard (L)

James Kelway (M)

Jubilee ! M )

Kelway's Glorious (M)

La Fiancee (M)

La Lorraine (M)

La Rosiere (M)

La Tendresse (E)

Le Cygne (E)

Marcelle Dessert (M)

Marie Lemoine (L)

Marie Jacquin (M)

Mme. Crousse (L)

Mme. de Verneville (E)

Mme. Emile Lemoine (M)

Mons. Dupont (M)

Mrs. Edw. Harding (M)

\section{BLUSH OR FLESH} COLORS

Albert Crousse (L)

Alfred de Musset (L)

Asa Gray (M)
Aurore (L)

Carnea Elegans (Calot)

(L)

Dorchester (L)

Elwood Pleas (L)

Eugenie Verdier (M)

Galathee (L)

Germaine Bigot (M)

Gismonda (L)

Grandiflora (L)

Henry Avery (M)

Jeannot ( $L$ )

Mlle. Leonie Calot (L)

Mile, Marie Calot (L)

Mlle. Rousseau (M)

Mme. Auguste Dessert

Mme. Calot (E)

Mme. de Galhau (L)

Mme. de Vatry (M)

Marguerite Gerard (M)

Marie Crousse (M)

Mary (M)

Milton Hill (L)

Number One (L)

Octavie Demay (E)

Pierre Duchartre (L)

Rosa Bonheur (M)

Solange (L)

Souv. de Louis Bigo

Therese (E)

Tourangelle (M)

Triomphe de
YELLOW

Dr. Bretonneau (Guerin) (M)

Duchess de Nemours (M) General Bertrand (E)

Duke of Wellington (M) Modeste (Guerin), (E)

Grandiflora Nivea Plena Mons. Barral (L)

(E)

Laura Dessert (E)

Philomele (M)

Primevere (M)

\section{MEDIUM PINK}

Eugene Verdier (L)

Gloire de Charles

$$
\text { bault (M) }
$$

Jeanne d'Árc (E)

Lady Alexandra Duff

La France (L)

Lamartine (M)

Livingstone (L)

Mme. Bollet (M)

Mme. Ducel (E)

Mme. Emile Galle (L)

Mme. Jules Dessert (L)

Mme. Lemonier (M)

Martha Bulloch (L)

Mortha Bulloch (L)

Rons. Jules Elie (E)

Reine Hortense (M)

Umbellata Rosea (E)

de Lille (M)
Mons. Boucharlat

(M)

Petite Renee (M)

Walter Faxon (M)

\section{RED}

Augustin d'Hour (M)

Eugene Bigot (M)

Felix Crousse (M)

Karl Rosenfield (E)

Longfellow (M)

Lord Kitchener (M)

Officinalis Rubra (E)

Rubra Superba (L)

DEEP RED AND PURPLE

Adolphe Rousseau (E)

Cherry Hill (E)

De Candolle (M)

Delachei (M)

Mme. Gaudichau (M)

Mons. Martin Cahuzac (E)

Prince de Talindyke (L)

Phillipe Rivoire (E)

Raphael (E)
Aine

(E)

\section{Japanese and Single Peonies-(Mostly Early to Midseason)}

WHITE

Eglantine (S)

Isani-Gidui (J)

La Fiancee (S)

Lemon Queen (J)

Lucienne (S)

Le Jour (S)

Marguerite Dessert (S)
WHITE

Queen of May (S)

Snow Wheel (J)

Whitleyi Major (S)

Yeso (J)

Rosy Dawn (S)

PINK

Emily (S)

Hermes (S)
PINK

Ama-No-Sode ( J )

Clairette (S)

Madeline Gauthier (S)

Pride of Langport (S)

Tokio ( J)

Venise (S)

Festiva Fragrans (S)

Tamatbako ( J)

For twenty-five years we have been interested in collecting and growing the best peonies. We have from time to time rejected varieties that did not come up to our high ideal, with the hope of reducing our list to 100 varieties. But many new varietiees have come out in recent years, some of which are superior to many of the older varieties. Thus we have been adding as well as rejecting, and our list now comprises only the best varieties.

The Best Size Roots to Buy

While our strong 3-5 eye roots will nearly all bloom for you the first year if planted in September, the 1-year size is the best buy, being about double the size at the price of only about one-half more.

Read on Page 5 what Secretary Saunders says about divisions.

\section{SPECIAL REMOVAL DISCOUNTS Shown on Page 5} Make This a Golden Opportunity For You 


\section{If In Doubt, Ask Us}

From the short descriptions in any peony list, the buyer is often at a loss to decide. We suggest, FIRST: Forget about prices; for many of the good ones are only $\$ 1.00$ or less: (e. g.) Festiva Maxima at $75 \mathrm{c}$ is unexcelled by any other white peony priced at lass than \$5.00. SECOND: Note carefully the rating. If a variety is rated 8.0 or above, you cannot go wrong, no matter how low the price, and there are quite a number below 8.0 that should be in every collection. No peony lover could do without Edulis Superba 7.6, Gloire de Chas. Gombault 7.9, Mme. de Verneville 7.9, or Mme. Crousse and Mme. de Galhau 7.5. THIRD: Be sure to place your order with a reliable house, even though prices may be a little higher, and, where possible, order nothing less than one or two year plants, preferably the latter.

\section{These Peony Discounts Will Interest You}

On orders of not less than three plants of a kind and amounting to $\$ 10.00$ to $\$ 50.00$, we will make a discount of 15 per cent.; on orders of $\$ 50.00$ and up, 20 per cent. On varieties priced at $\$ 2.00$ and up prices are net. Write for special quotation on large orders.
No charge for boxing and packing.

Discounts do not apply to special offer.

The best discount we can give is Mrs. Harding's book, "Peonies in the Little Garden", with every order for $\$ 15$ for Peonies and lris.

It will be to your interest to order at once to s cure the plants you wish. Some of the varieties will be sold out before planting time.

\section{To those wishing plants fur mass nlanting, or cut-flowers, and C not particular about names we offer a bargain. Strong 3 to 5 NeC eye divisions, $\$ 2.50$ per ten; $\$ 20.00$ per 100 . Strong 1 -year
clumps, $\$ 4.00$ per ten; $\$ 35.00$ per $100 ; 50$ at 100 rate. 10 pink, white or red, divisions, 30 cents each; 50 or more at 25 cents each; 1-year, 45 cents each, 50 or more at 40 cents each. \\ If you could have had this special offer and seen our plants in bloom in June your order would be a large one.}

\section{IMPORTANT}

Concerning the sizes of plants, Prof. Saunders well says: "I feel that I should not lay down my typewriter without saying a word regarding a new practice which has come into the Peony business of late years I refer to the selling of what are called 'divisions' or 'one-eye divisions,' 'two-eye divisions,' etc. What are called one-year roots are the plants that have resulted from the divisions of last year. But evidently the nurseryman can save himself money by selling the divisions at once to his customers, without taking the trouble to replant and cultivate for a year. These freshly made divisions are very commonly offered in the trade and at prices much below those for one-year roo:s. My own judgment on it is this: where the question of price has to be very carefuliy considered and the question of time is a matter of indifference, the buyer may probably do well to buy divisions of the expensive sorts. BUT WHAT HE SAVES IN MONEY HE LOSES IN TIME; FOR WHEREAS A ONE-YEAR ROOT WILL USUALLY BLOOM WELL WITHIN TWO OR THREE YEARS AFTER PLANTING, AND WILL GiVE SOME BLOOM EVEN THE FIRST YEAR, A DIVISION CANNOT BE EXPECTED TO GIVE GOOD BLOOM FOR A CONSIDERABLY LONGER TIME. *** But no one need spend a great deal of money in order to have a beautiful collection of Peonies, provided he is willing to confine himself to the older sorts. Those who must have the novelties cannot do better than take counsel with others who have tried the experiment of small divisions before committing themselves too far."

Much might be added to what Prof. Saunders says about these small divisions. Mrs. Harding has well covered the case in her little book about Peonies which we are ofiering as a prize and we sincerely hope buyers will take heed of what these good authorities say and that the custom of selling small divisions will be done away. These small divisions in the high priced varieties may be worth while by experts, but for the amateur, it would seem to me ill-advised to purchase anything less than the 3-5 eye divisions.

We wish prospective customers could see our fine fields of one year plants grown strong and husky from 3-5 eye divisions planted last Fall. Although we have taken pains to plant and care for these roots a whole year, giving them time to make a year's growth and heal all bruises and cuts, nevertheless- we are offering these plants at prices lower than divisions are offered in some quarters, in accordance with our motto, "Prices as low as consistent with highest quality." 


\section{Description and Price List of Peonies}

The varieties we offer are arranged in two classes, double and single, in each of which the names are arranged alphabetically, and where known, the name and date of the introducer immediately follows in parenthesis. As color comes first in the choice of Peonies, we have placed the color on the same line as the name. Size and type naturally appeal next, and so follow the color. Having found these satisfactory in any variety described, one naturally next looks for th 3 character and habit of the plant. To further aid purchasers we have made an alphabetical list of colors. S ₹e page 4. In addition, we shall be pleased to give by letter further information to intending purchasers.

\section{DOUBLE PEONIES}

\section{SINGLE PEONIES-SEE PAGE 10}

8.5 Adolphe Rousseau. (Dessert and Mechin, 1890). Glossy, purplish garnet; one of 3-5 the darkest. Very large; semi-double; very tall. Early midseason. A great eye favorite, awarded first prize at American Peony Show 1923 over Mons. Div.

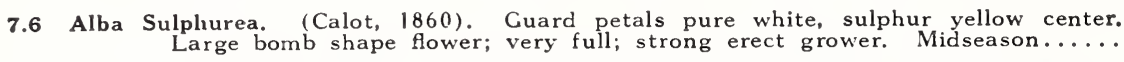

8.7 Albatre. (Crousse, 1885). Milk-white center, petals tinged lilac. Large, rose type, pleasant fragrance; medium height. Midseason. Strong, vigorous grower..

Prof. Saunders well says: "An old and cheap sort produces, when well grown, flowers that will stand comparison with anything there is."

8.6 Albert Crousse. (Crousse, 1893). Very fresh salmon-pink, delicate color. Large

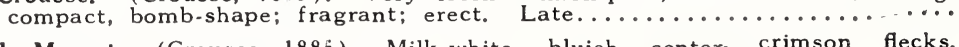

7.4 Alfred de Musset. (Crousse, 1885). Milk-white, bluish center crimson flecks.

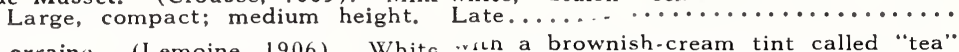

8.8 Alsace-Lorraine. (Lemoine, 1906). White wstn a brownish-cream tint called "tea" color. Flowers medium. . pening like a water lily. Strong grower; free

bloomer. Mechin. (Mechin, 1880). Large blooms and clusters; red, shaded gar.

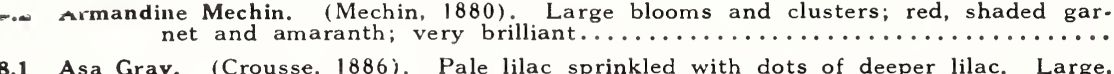
rose shape; very fragrant; medium height and habit. Midseason..........
d'Hour, (Calot, 1867). Dark, brilliant rose-red. Medium to large, bomb.

7.8 Augustin d'Hour. (Calot, 1867). Dark, brilliant rose-red. Medium to large, bombshape; showy bloom; medium height. Midseason. (Similar in color to Felix

8.0 Aurore. (Dessert, 1904). Blush, lighter collar, slightly flecked with crimson. Large,

8.7 Avalanche. (Crousse, 1886). Creamy-white, slightly flecked with carmine. Large, compact, crown type; fragrant; strong growth. Nothing better. Often sold

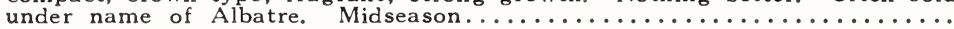

9.0 Baroness Schroeder. (Kelway 1889). Flesh, fading to milk-white. Large globular,
rose type, very fragrant; strong free bloomer. One of the best standard

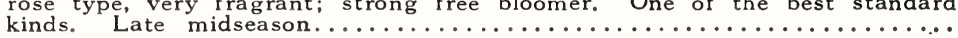

8.0 Boule de Neige. (Calot, 1867). Milk-white, flecked with crimson. Very large, reg-

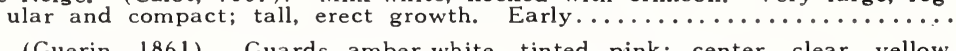

7.0 Canari. (Guerin, 1861). Guards amber-white, tinted pink; center clear yellow,

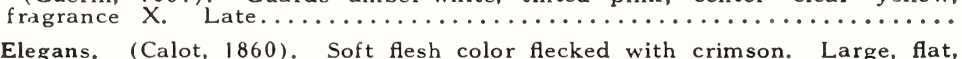

7.8 Carnea Elegans. (Calot, 1860). Soft flesh color flecked with crimson. Large, flat, compact, rose type; fragrant; medium height, late. Professor Saunders well savs: "Indoors tuey preserve an enchant.ng combination or flesn color and Hill. Semi-rose type, Deep garnet, decided sheen. Tall and erect. Mid.

8.7 Claire Dubois. (Crousse, 1886). Even, clear, satiny pink, tipped white. Very large,

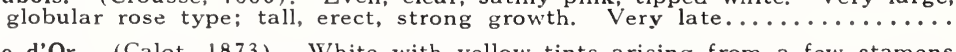

8.1 Couronne d'Or. (Calot, 1873). White with yellow tints arising from a few stamens showing amidst the petals. Center petals tipped with carmine. Large, rather full flower of superb form. Strong grower and very free bloomer. rather full flower of superb form. Strong grower and very free bloomer.

7.2 De Candolle. (Crousse, 1880). Uniform bright lilac-purple; beautiful under artificial light. Very large, full, rose type; medium height; strong erect grower.

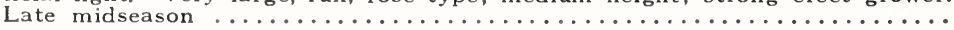

7.1 Delachei. (Delache, 1856). Violet-crimson. Medium size; semi-rose type; strong,

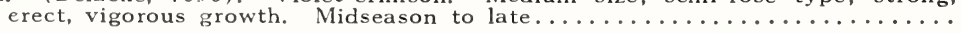

6.9 Docteur Bretonneau. (Guerin, 1850). Guards flesh-pink, center yellow, sometimes

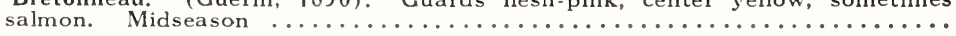

7.7 Dorchester. Delicate shade of hydrangea pink, compact rose type. Very late...

7.8 Duc de Wellington. (Calot, 1859). Pure white guards, sulphur center. Large, bomb-shape; very fragrant; tall, erect growth. Midseason............

In comparing prices with those of other growers, please note that we offer strong one and two year plants, and large divisions, 3-5 eye. These one year plants have grown from strong divisions made one year ago, which has given time to heal the callouses and produce plenty of fibrous roots. That such plants are much more valuable than divisions goes without saying. 
8.1 Duchess de Nemours. (Calot, 1856). Guard petals white, center lemon-yellow, cup- 3-5 shaped at first; it develops into a large bloom, gradually fading to white; eye fragrant; strong grower and free bloomer. Extra good commercial variety.

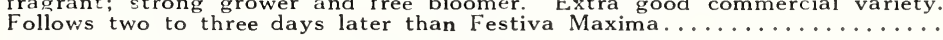

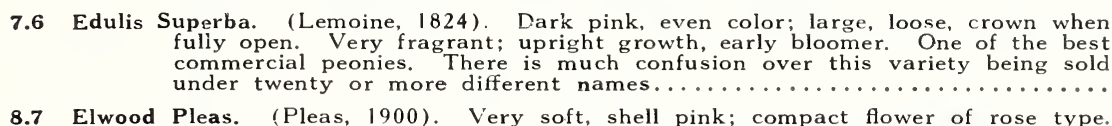

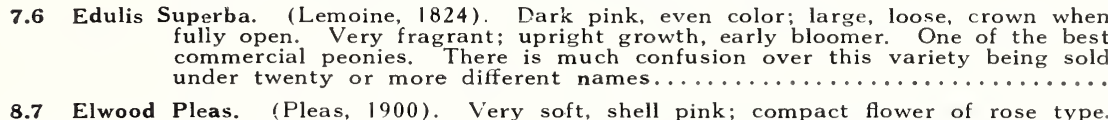

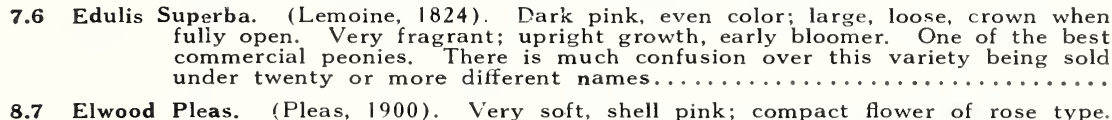

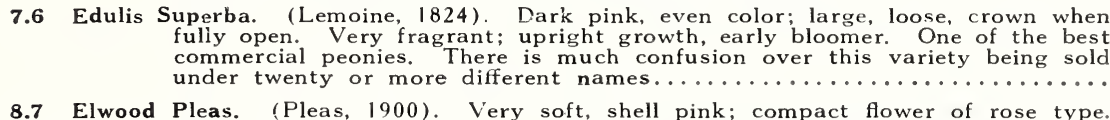

8.7 Elwood Pleas. (Pleas, 1900). Very soft, shell pink; compact flower of rose type.
Strong grower, free bloomer. Large, fragrant and beautiful. Late....... Strong grower, free bloomer. Large, fragrant and beautiful. Late.......
Bigot. (Dessert, 1894) Brilliant red, medium size, compact, globular,

8.3 Eugene Bigot. (Dessert, 1894), Brilliant red, medium size, compact, globular,

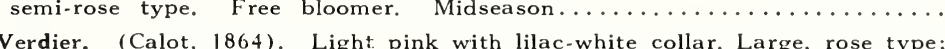

83 Eugene Verdier. (Calot, 1864). Light pink with lilac-white collar. Large, rose type; extra strong-growing plant; erect, rather dwarf. Fragrant. Awarded first
prize American Peony Show i 923 for six specimen blooms, named, one variety. Late. Be sure you get the real thing; it is one of the best.......

8.6 Eugenie Verdier. (Calot, 1864). (Also called Pottsi Alba). Pale pink, center deeper, flecked crimson. Large tlat, rose type, rather loose; fragrant; tall, free.

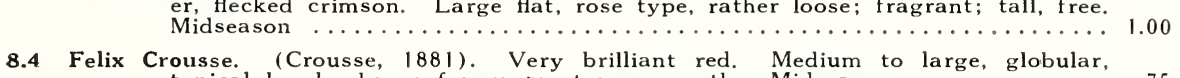
typical bomb shape; fragrant; strong growth. Midseason............

8.0 Festiva. (Donkalaer, 1838). Pure paper white with crimson markings in center.

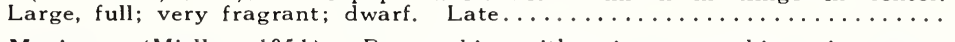

9.3 Festiva Maxima. (Miellez, 1851). Paper-white with crimson markings in center. Very large and full, rose type; very tall, strong growth. The best early

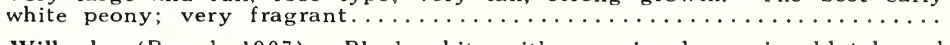

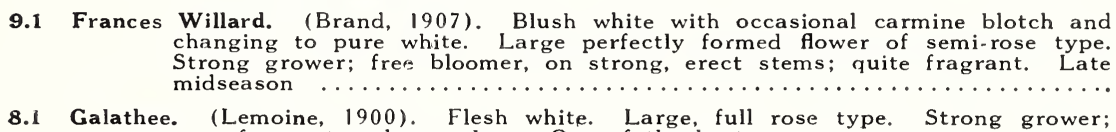

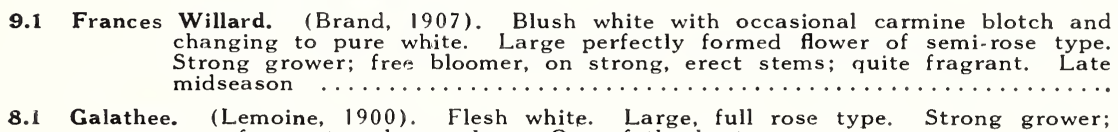

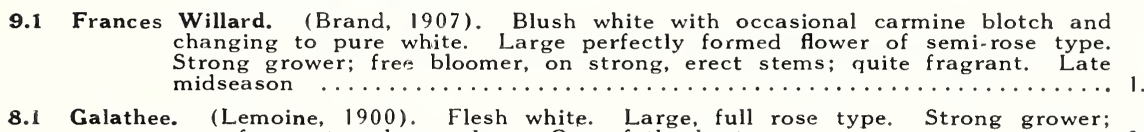

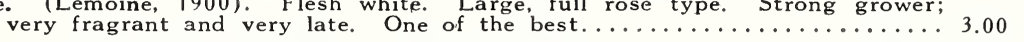

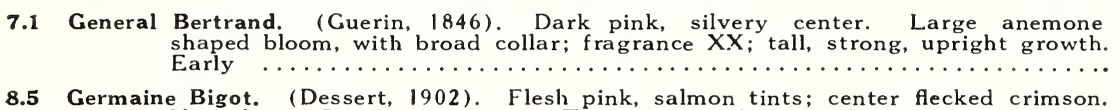
Very large flower, rose type. This is one of Dessert's excellent varieties. Ever since we imported it from him, 15 years ago, we have thought very highly of it. It is not only beautiful in color, but its large blooms are borne in great profusion, standing up well on strong stems. Excellent mid-

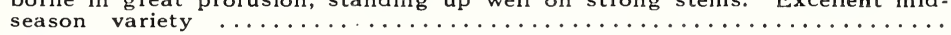

8.4 Gismonda (Crousse). This is a very good fragrant Peony; blooms are flesh colored,

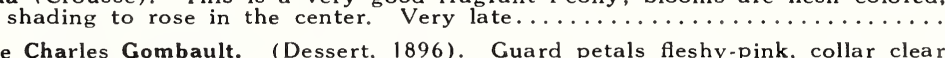
salmon-flesh shaded with apricot; center petals flesh-pink, striped with carmine. Flowers very showy, on tall stems in great profusion; crown type.

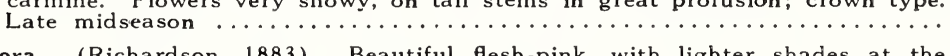

8.8 Grandiflora. (Richardson, 1883). Beautiful flesh-pink, with lighter shades at the center. One of the very largest pinks known. Vigorous, fragrant. One of

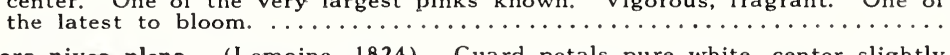

8.1 Grandiflora nivea plena. (Lemoine, 1824). Guard petals pure white, center slightly tinged sulphur and pink, and flecked with crimson. Very large, rose type;

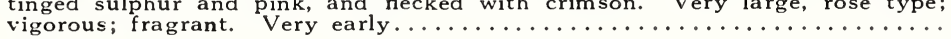

8.8 Henry Avery. Guard petals and center, light flesh pink; collar clear bright yellow.

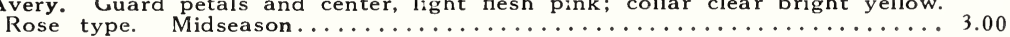
Kelway. (Kelway, 1900). Rosy white changing to milk white. Very large,

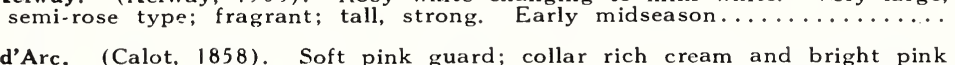
d'Arc. (Calot, 1858). Soft pink guard; collar rich cream and bright pink
tufted center, tipped carmine. Medium to large, crown shape; fragrant; strong grower, free bloomer. Early midseason. One of the choicest of older varieties. Peach-blossom pink and cream, reminds one of peaches and

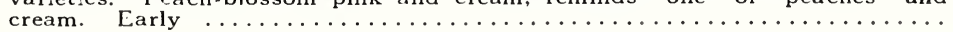

9.2 Jeannot. Flesh pink, slightly tinged purple. Large cup-shaped flowers. Late.... 5.00

8.9 Jubilee. (Pleas, 1908). Color flesh white, fading to pure white. Petals narrow, (Pleas, 1908). Color flesh white, fading to pure white. Petals narrow,
loosely arranged, giving a feathery effect. Long stems. Strong grower.

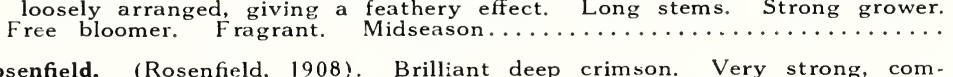

8.8 Karl Rosenfield. (Rosenfield, 1908). Brilliant deep crimson. Very strong, com-

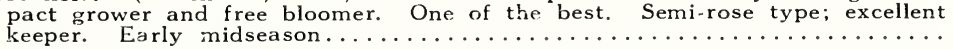

9.8 Kelway's Glorious. (Kelway, 1909). Creamy-white, with a soft blush of pink. Glorious. (Kelway, 1909). Creamy-white, with a soft blush of pink.
Enormous blooms of rose type; very fragrant, Generally considered one of

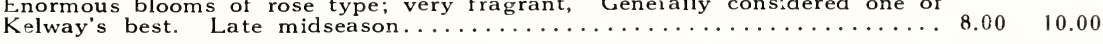

Everyone who grows Peonies chould hive Mrs. Harding's new book, "Peonies In the Little Garden." Page 5, you will sec how to obtain this admirable book Free. The chep:er on Selection of Varieties and Special Lists is alone worth the price of the book. There is really more sound Peony information packed in the nine interesting chapsers of this book than can be found in any other book. If you already have in the nine interesting chapsers of this book than can be
the book we will give you as a premium any $\$ 1.50$ Pcony. 
9.1 Lady A'exandra Duff. (Kelway, 1902). Outer petals delicate pink, gradually shading lighter toward center. An immense cup-shape flower; broad, imbricated petals, large and full in old plants. In young plants and the side buds of older plants, blocms are water lily shape, showing yellow stamens at center. Fragrant, tall and robust, One of Kelway's best. True variety from Shaylor.

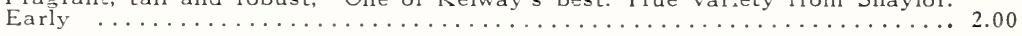

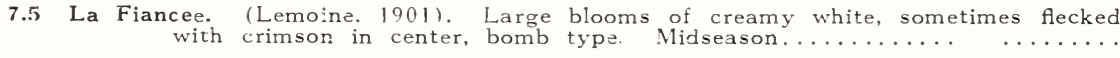
3-5 $\quad 1 \quad 2$ eye yr. yr

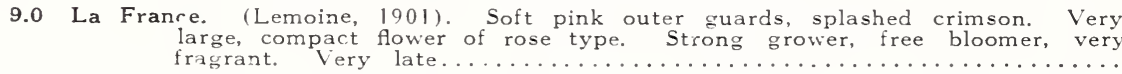

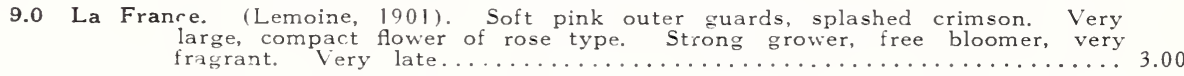

8.6 La Lorraine. (Lemoine, 1901). Creamy white with a faint salmon pink tinge; very large, globular flower. Late midseason........................ 5.00

8.3 Lamartine. (Calot, 1860). (Also called G:gantea). Pale l'lac-rose, darker center. Very large, loose, irregular, rose shape; tall, free bloomer; very fragrant.

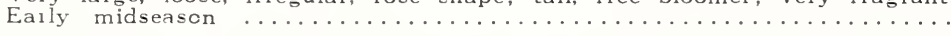

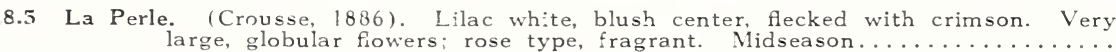

8.3 La Rosiere. (Crousse, 1888). Pure white shading to cream in center, due to presence of yellow stamens. Large, flat, semi-double; medium height. Name is well chosen for its strong fragrance. Midseason. American Peony Society award 1923, for twenty blooms, double, named, white or cream......

8.1 La Tendresse. (Crousse, 1896). Cream color, changing to pure white, slightly splashed carmine; rose type; very large, compact, flat; fragrant. Strong,

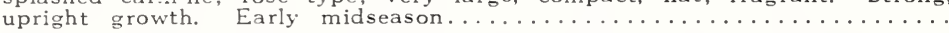

8.s Laura Dessert. (Dessert, 1913). Guards, cream white; center, bright canary yellow. Large, full flower; rose type: superb. Early. Like other yellow peonies, it should be opened in the house to retain its rich yellow...... 4.00

9.9. Le Cygne. (Lemoine, 1907). Milk white flower. Petals incurved. Perfectly formed, enormous globular flower. Very fragrant. Early............ 7.00

8.1 Livingstone. (Crousse, 1879). Soft rose pink, silver tipped, some carmine spots. Large, compact, rose type; tall, vigorous, free bloomer. Very late......

9.0 Longfellow. (Brand, 1907). Bright crimson with cherry tone; perhaps the most brilliant of red peonies. Erect habit, vivid color, long season, rare value.

Originator says, "It is the most brilliant peony in our whole list." Midseason 2.50
7.8 Lord Kitchener. Bright cherry red. Large bomb type fowers. Midseason........

86 Mme. Auguste Dessert. (Dessert, 1899). Glossy flesh, slightly tinged carmine; center flecked crimson. Very large, imbricated, cup-shaped flower, rose type;

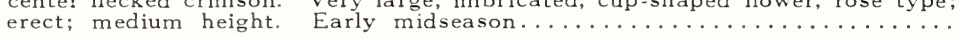

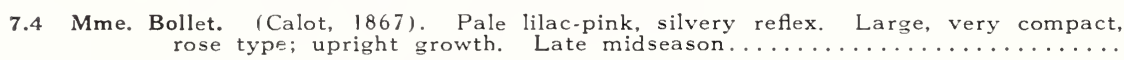

7.3 Mme. Bucquet. (Dessert, 1888). Dark crimson amaranth. Semi-double flowers;

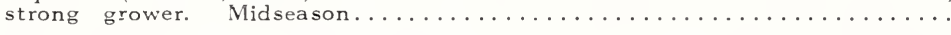

8.1 Mme. Calot. (Miellez, 1856). Flesh white, tinged pale hydrangea pink, center shaded slightly darker with a sulphur tint; very large, full, globular bloom; fragrant; early and abundant bloomer. On well established plants the flowers are ex-

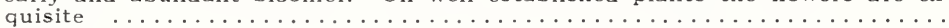

6.8 Mime. Chaumy, Pale lilac rose with silvery reflex. Large globular flowers; rose

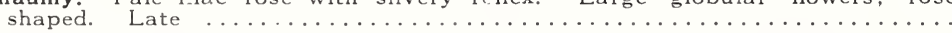

7.9 Mme. Crousse. (Calot, 1866). Pure white with faint crimson markings. Large, globular, crown type; fragrant; medium height. Late midseason........

7.5 Mme. de Galhau. (Crousse, 1883). Delicate pink with a rose-white collar. Very large, compact, rose shape; very fragrant; strong growth. Very late....

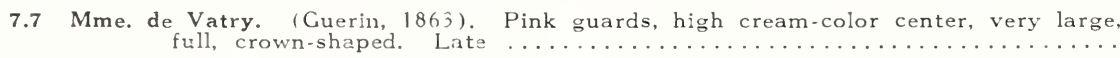

7.9 Mme. de Verneville. (Crousse, 1885). Pure white, center tipped with carmine, very large, full bomb shape, fragrant, medium height, strong growth, very

7.9 Mme. Ducel. (Mechin, 1880). Bright silvery pink. Very large, well built flower; bomb type; strong grower; free bloomer; odor pleasant; medium height; one

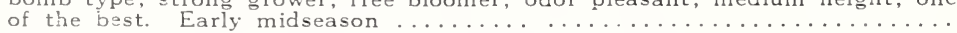

8.5 Mme. Emile Galle. (Crousse, 1881). Very soft pink, changing to milk-white in center. Very large, compact, flat, rose type; tall, fragrant. Late........

8.9 Mme. Emile Lemoine. (Lemoine, 1899). Clossy white, tinged pale pink and covered
with tiny dots of deeper shade. Large, globular, rose type; a strong grower,

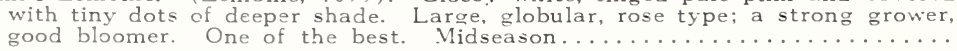

8.8 Mme. Gaudichau. Very dark maroon. Foliage dark red when first appearing. Mid.

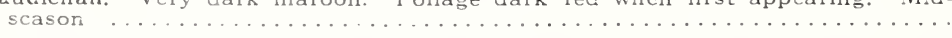

9.4 Mme. Jules Dessert. (Dessert. 1909). Clear pink, tinged flesh and straw yellow. undulated central petals, flecked with carmine and intermixed with a few visible golden stamens. Very large, imbricated flower of fine shape; one of the most beautiful in color and form. When the flower opens under cloudy weather, or in the house, the exquisite tints are really marvelous. Only four peonies rank higher than this. Late midseason. Price has increased with

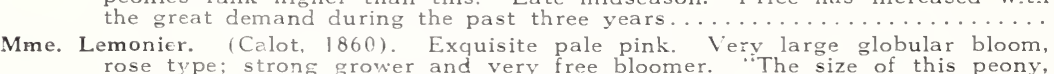
rose type; strong grower and very free bloomer. "The size of this peony, subject." Midseason. Much superior to Mme. Lemoinier, 1865, which is

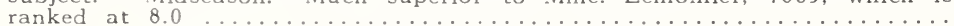


3-5

eye

7.3 Mme. Reignoux. (Dessert, 1909). Rose-carmine, large and full. Free flowering... Mlle. Leonie Calot. (Calot, 1861). Very delicate shell-pink, center darker. Medium size, very compact, globular. Late midseason. Its only fault a rather weak

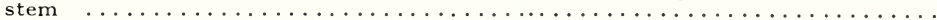

7.4. Mlle. Marie Calot. (Calot, 1872). Milk-white tinged flesh, flecked crimson. Large, rose type; very fragrant; strong grower. Late midseason..............

8.1 Mlle. Rousseau. (Crousse, 1886). Milk-white, splashed carmine. Large globular, rose type; extra strong stem; medium height. Late midseason..........

8.2 Marcelle Dessert. (Dessert, 1899). Milk-white, slightly splashed with lilac; high crowned, flecked crimson. Fragrance of a tea rose. Midseason...........

8.4 Marguerite Gerard. (Crousse, 1892). Very pale salmon-pink, fading to almost white Large, compact, rose type; very strong growth. Free bloomer. Late mid-

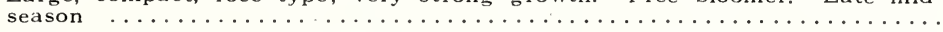

8.9 Marie Crousse. (Crousse, 1892). Soft salmon-pink. Large, full flower; bomb type; borne on stiff stems; very fragrant; tall, strong. Midseason............ 1.00

8.3 Marie Jacquin. (Verdier). (Syn. Water Lily). Rose-white, fading to white. Large, globular, semi-double; upright, very strong growth; cup-shaped like a water

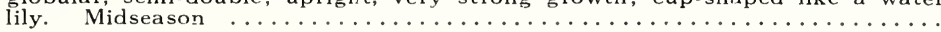

8.5 Marie Lemoine. (Calot, 1869). Pure white with cream-white center. Large, very compact, rose type; pleasing fragrance; medium height, extra strong stems. One of the best; no coliection is complete without it. Very late.........

9.1 Martha Bulloch. (Brand, 1907). Soft rose pink. Enormous cup-shaped flower. One of the best peonies in existence and exquisitely beautiful. Strong grower.

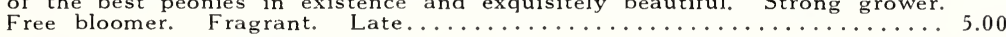

9.4 Mary Woodbury Shaylor. (Shaylor, 1916). The guard petals of the flower are fresh shell pink and the center a creamy yellow. Plant of dwarf growth with stiff stems, very profuse bloomer........................ 5.00 Hill. (Richardson). Soft, clear, flesh color, deepening toward the center. "There is in this flower a quality of color that is beyond the power of words to describe." Very large globular, compact, rose type; fragrant. Very late. 3.00

9.0 Milton Guerin. (Guerin, 184j). Very attractive, bright pink, tinged carmine, solid color; large bloom, typical bomb type; fragrance XX. Fine upright habit, very vigorous, early and free. We consider this the best carmine-pink peony.

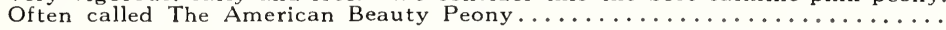

8.3 Mons. Dupont. (Calot, 1872). Milk-white, center splashed with crimson. Large cup-shaped, semi-rose type; fragrant; tall, erect. Late midseason........

9.2 Mons. Jules Elie. (Crousse, 1888). Pale lilac-rose, silv̈ery reflex. Very large, compact, globular; very fragrant; tall, vigorous growth. Early............ 1.00

8.8 Mons. Martin Cahuzac. (Dessert, 1899). Very dark garnet with black reflex, petals so glossy as to appear varnished. Medium to large, globular, semi-rose type. Medium height; strong, vigorous grower. Early midseason............ 2.00

9.3 Mrs. Edward Harding. Pure white Hower. Semi-rose type. Late midseason......12.00

Number One-Unnamed, imported variety; exquisite shell pink flower of large size and beautiful form; center splashed with crimson after the manner of Festiva Maxima. Rose type; very late. It excels in attractiveness many of the highest priced peonies. A royal variety; greatly admired by all who see it.. 1.00

8.5 Octavie Demay. (Calot, 1867). Pale pink, collar almost white with a few stripes of carmine. Very large, flat, crown type; fragrant; dwarf plant with strong,

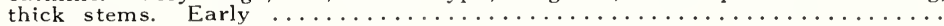

Officinalis Rubra. Double crimson, of large size; fragrant; the old-fashioned red

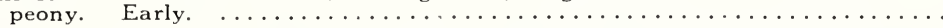

7.7 Philomele. (Calot, 1861). Yellow, fading to cream, with bright pink guards and crown; medium size; low, flat crown; medium height; strong growth; fra.

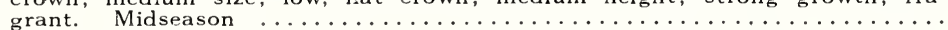

7.6 Petite Renee. (Dessert, 1899). Dark pink. Very large, anemone shape, semi-double with thread-like center petals. Medium height, upright. Midseason..... 1.00

9.2 Phillipe Rivoire. (Rivoire, 1911). This is one of the finest red Peonies. Of excellent form and color this Peony has the fragrance of a tea rose. Strong grower and free bloomer. Midseason ......................... 7.50

7.6 Pierre Dessert. (Mechin, 1890). Dark red shaded garnet. Semi-rose type. Early.

8.2 Pierre Ducharte. (Crousse, 1895). Flesh-pink. Very full, cup-shaped flower, rose

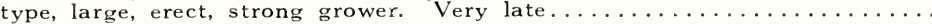

8.6 Primevere. (Lemoine, 1907). Outer petals buff, center sulphur yellow. Tall, strong,

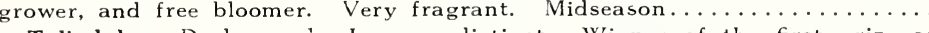

6.7 Prince de Talindyke. Dark purple. Large; distinct. Winner of the first prize at Boston, American Peony Society Exhibition, June, 1910, for fifty best blooms, crimson varieties. Stems erect and vigorous; nearly four feet tall. Late...

9.0 Raoul Dessert. (Dessert, 1910). Clear mauve shaded carmine pink; very full, big flower of perfect shape; free bloomer; a variety of great beauty, in great de.

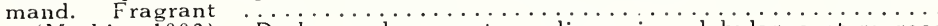

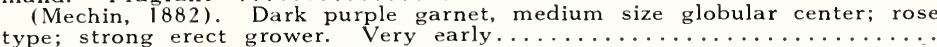

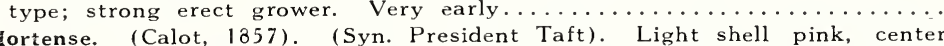
flecked crimson; very striking; large, well formed flowers, semi-rose type,

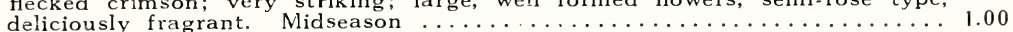

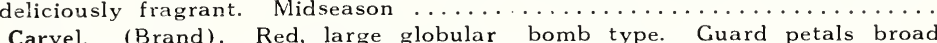

8.8 Richard Carvel. (Brand). Red, large globular bomb type. Guard petals broad

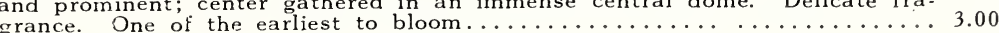


9.0 Rosa Bonleur. (Dessert, 1905). Fleshy pink, imbricated flower; rose type, dwarf eye plant; very free bloomer in clusters. One of the best. Midseason........2.50

7.2 Rubra Superba. (Richardson, 1871). Deep carmine-crimson. Large, fragrant, rose

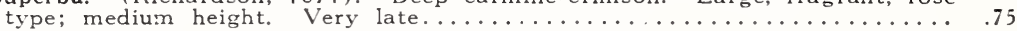

9.0 Sarah Bernhardt. (Lemoine, 1906). A soft pink, large and full; evenly formed, very fragrant. Ranked among the twelve best peonies by twenty-three peony growers; one of Lemoine's best. Strong grower; profuse bloomer. Late mid. season. Awarded Ist prize 1926 Exhibition of Am. Peony Society.........

9.7 Solange. (Lemoine, 1907). The outer petals are very delicate lilac white, deepening toward the center with salmon shading; center deep orange salmon. A very large, full, compact flower of rose type; strong grower and free bloomer; delightfully fragrant. Very late. No better peony exists. Awarded first prize at American Peony Show 1923 for one specimen bloom, double, any variety, representing the best bloom at the Show; was as good the last day

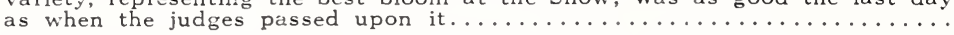
9.1 Souv. de Louis Bigot. (Dessert, 1913). Rich salmon pink with silvery lights. Very
large blooms, extra fine, late midseason. Mrs. Harding says it is a real treasure. Its effect in the garden is nothing short of gorgeous........ 3.50

9.8 Therese. (Dessert, 1904). Glossy flesh, lightly shaded pink, lighter at the center. Very attractive imbricated flowers, very large; rose type; one of the most beautiful flowers in color and form; very scarce. Early............. 2.50

9.4 Tourangelle. (Dessert, 1910). Flesh-pink, tinged with salmon; very delicate shade. Large Hat flower of rose type, strong grower; free bloomer; very fragrant;

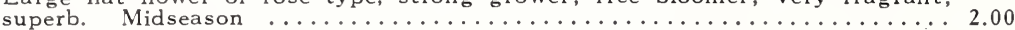

7.8 Triomphe de l'Exposition de Lille. (Calot, 1865). Light shell pink, splashed with a darker tint. Large, compact, rose type; pleasing fragrance; strong growth.

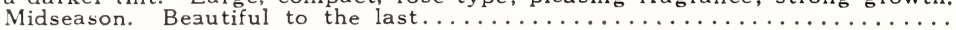

7.1 Umbellata rosea. (Dessert, 1895). Violet-rose guards with amber-white center. Informal rose type; medium height; very strong; upright. Very early.....

8.3 Venus. (Kelway). Very delicate, shell pink, lighter collar. Very large, high compact crown; rose fragrance; tall, erect. Midseason................

7.1 Ville de Nancy. (Calot, 1872). Brilliant red; very large, bomb shape, very strong grower. Late ................................ 50

9.3 Walter Faxon. (Richardson). Coral salmon pink; very distinct delicate color, deepening toward the center; semi-rose type. Strong grower and free

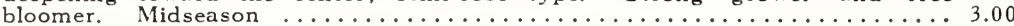

\section{SINGLE AND JAPANESE PEONIES}

9.2 Ama-no-sode. (Japan). Bright Rose Pink, shading lighter to the edge. Superb.... 8.00 Carnot. (Dessert). Single, red. Early............................

8.5 Clairette. (Dessert, 1905). A superb, large white, lightly shaded pink, changing to

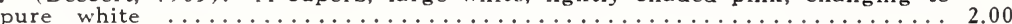

7.1 Darkness. Single. Very dark maroon surrounding cluster of golden stamens...... 1.00

8.1 Eglantine. (Dessert, 1913). Large, white, single flower, slightly tinted carmine, central tuft of golden stamens. Superb variety, like a gigantic Eglantine

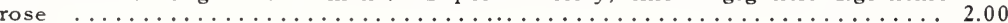

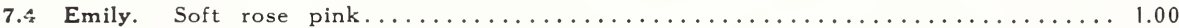

Festiva Fragrans. Clear single pink..............................

.2 Fuyajo. (Japan). Guard petals deep red with dark crimson petaloids in center.... 6.00

Hermes. Single. Soft shade of deep shell pink.....................

9.3 Isani-Gidui. (Japan). Very large, pure white, single flower, with silky broad petals, big central tuft of golden yellow stamens or filamentous petals; strong
grower and free bloomer. A splendid variety of marvelous beauty. One

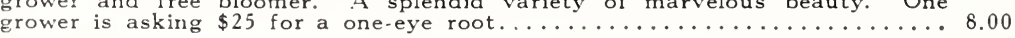

8.2 Kino-Kimo. (Japan). Crimson-carmine; large central tuft of filamentous petals golden yellow, streaked with carmine...........................

8.4 La Fiancee. (Dessert, 1902). (Syn.-The Bride). Very large, single, white with yellow center. Early. Good variety. Carpels greenish-white and hairy; stigmas long, white and recurved. Odor slight. Plant is strong, coarse grower, with a very spreading habit. Free bloomer. Characteristic coarse, thick, leathery foliage; a third larger bloom than the ordinary albiflora..... 1.75

8.6 Le Jour. Single. Very large white of extra quality ..................

Lemon Queen. (Japan). Fure white with central cushion of short, fringed yellow petals (Japan). Pure white with central cushion of short, fringed yellow 1.00

8.4 L'Etincelante. (Dessert, 1905). Very broad petals of the finest bright carmine, broad silvery border, crown or gold stamens at the center; semi-double; 1.50

7.7 Lucienne, (Dessert, 1908). Large, white, single flower, very slightly tinted purple fading to pure white. Central tuft of golden stamens. Very strong grower

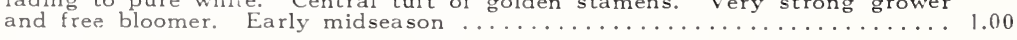

8.5 Madeline Gauthier. (Dessert). Single. Rich and fine silvery fleshy pink, exquisite

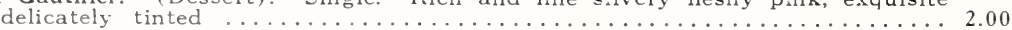

8.5 Marguerite Dessert. (Dessert, 1913). Pure white, entirely powdered and splashed with carmine; central tuft of golden stamens; one of the most exquisite varieties. Large single flower; very attractive, Early............. 3.00 


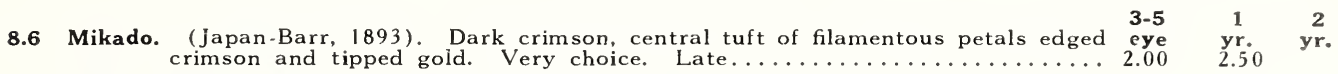

Number 1001. A very beautiful single Peony, similar in texture and color to Tokio and Ama-no-sode. The yellow stamens form a heavy tuft, like the Japanese Peonies, but do not change their color to correspond with the petals. lt is somewhat dwarf and the flowers are a little smaller than those of Tokio....

8.9 Pride of Langport. (Kelway). Distinct shade of brilliant peach pink, wonderfully

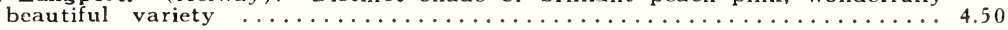

8.5 Rosy Dawn. (Barr). Large white petals tinged blush, resembling a large water

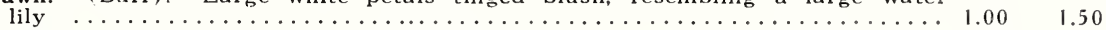

Queen of May. One of the finest single whites $\ldots \ldots \ldots \ldots \ldots \ldots$

Snow Wheel. (Japan). Medium sized flower with clear white guards..........2.00

9.0 Some Ganoko. (Japan). Velvety dark red guards; center golden yellow slightly

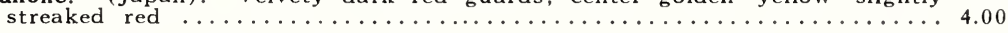

Tamatbako. (Japan). Broad petals of clear soft pink, a little darker than Tokio.

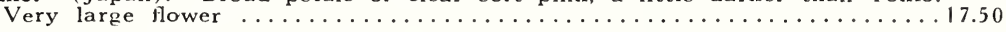

The Moor. Single. Rich purple-garnet. Medium size flower; strong grower; free

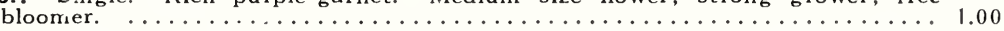

9 Tokio. (Jap. Dessert, 1910). Color, old rose; very large, showing a central tuft of golden flamentous petals. Beautiful variety, strong grower, and free bloomer. Very choice. Best all a round Jap........................

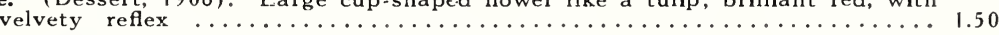

Venise. (Dessert). Bright lively pink, slightly tinted with carmine, central tuft of

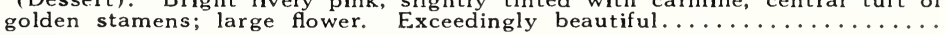

Whitleyi Major. Single. Large pure white flowers. Vigorous grower; free bloomer. 1.50

7.7 Yeso. (Dessert, 1910). Cuard petals pure white, narrow central petals white tinged straw yellow, and tipped with a little carmine point....................

Yoochinatsuki. (Japan). Exceedingly beautiful white Peony with the petaloids

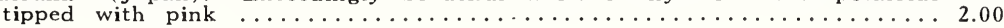

Those wishing to plant perennial gardens should take up the matter at once, have the ground prepared so that the plants may be set early in September. If perennials are set late in the fall or in spring, they give very little bloom the first year. Set early in the fall, they become thoroughly established and give a good account of themselves the following summer.

We are always glad to assist our customers in making a selection of Peonies, Phlox, Iris, etc. Please state fully the results desired, size of plot to be planted, etc.

\section{DON'T OVERLOOK THESE CONVENIENT COLLE.CTIONS}

Below are four collections, carefully made, regardless of price, to cover all colors, early (E), midseason $(M)$, and late (L) bloom, of varieties anyone might be happy to own. If desired however, substitutes may be made by the purchaser. Please note low prices for one-year plants, all of which will bloom next year.

\begin{tabular}{|c|c|c|c|c|c|}
\hline $\begin{array}{l}\text { COLLECTION No. } 1 \\
\text { White and Yellow }\end{array}$ & $\begin{array}{l}\text { 3-5 eye } \\
\text { Div. }\end{array}$ & 1 -Yr. & $\begin{array}{l}\text { COLLECTION No. } 2 \\
\text { White and Yellow }\end{array}$ & $\begin{array}{l}\text { 3-5 eye } \\
\text { Div. }\end{array}$ & $1-Y_{r}$ \\
\hline 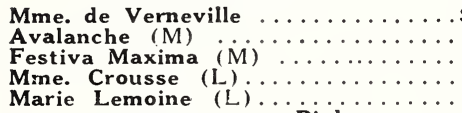 & $\begin{array}{l}.50 \\
.75 \\
.50 \\
.50 \\
.75\end{array}$ & $\begin{array}{r}\$ .75 \\
1.00 \\
.75 \\
.75 \\
1.00\end{array}$ & 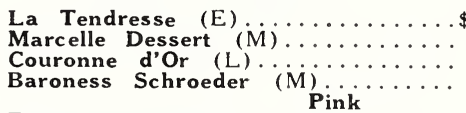 & $\begin{array}{r}.75 \\
1.00 \\
.75 \\
1.00\end{array}$ & $\begin{array}{r}1.00 \\
1.50 \\
1.00 \\
1.50\end{array}$ \\
\hline 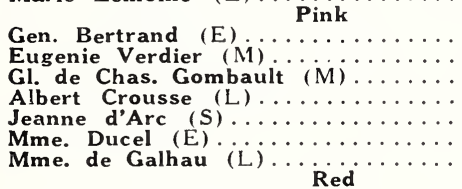 & $\begin{array}{r}.50 \\
1.00 \\
1.00 \\
.75 \\
.75 \\
.50 \\
50\end{array}$ & $\begin{array}{r}.75 \\
1.50 \\
1.50 \\
1.00 \\
1.00 \\
1.00 \\
.75\end{array}$ & 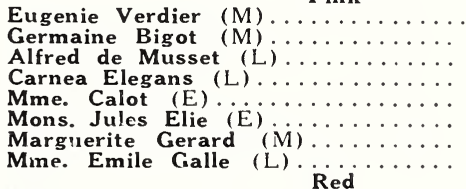 & $\begin{array}{r}1.00 \\
.75 \\
.75 \\
.75 \\
.50 \\
1.00 \\
.75 \\
1.00\end{array}$ & $\begin{array}{l}1.50 \\
1.25 \\
1.00 \\
1.00 \\
.75 \\
1.50 \\
1.00 \\
1.50\end{array}$ \\
\hline $\begin{array}{l}\text { Felix Crousse }(M) \ldots \ldots \\
\text { Prince de Talindyke }(\mathrm{L}) \ldots \ldots \ldots \ldots \\
\text { Karl Rosenfield (E) } \ldots \ldots \ldots \ldots \ldots \ldots\end{array}$ & $\begin{array}{l}.75 \\
.75 \\
.75\end{array}$ & $\begin{array}{l}1.00 \\
1.00 \\
1.00\end{array}$ & $\begin{array}{l}\text { Mikado, Single }(\mathrm{L}) \ldots \ldots \ldots \ldots \ldots \ldots \\
\text { Augustin d'Hour }(\mathrm{M}) \ldots \ldots \ldots \ldots \ldots \\
\text { Adolphe Rousseau }(\mathrm{E}) \ldots \ldots \ldots \ldots \ldots\end{array}$ & $\begin{array}{r}2.00 \\
.75 \\
1.50\end{array}$ & $\begin{array}{l}2.50 \\
1.00 \\
2.00\end{array}$ \\
\hline Net Price $\ldots \ldots \ldots \ldots \ldots \ldots$ & $\begin{array}{r}\$ 10.25 \\
8.50\end{array}$ & $\begin{array}{r}\$ 14.75 \\
12.00\end{array}$ & $\ldots \ldots \ldots$ & $\begin{array}{l}\$ 14.25 \\
11.50\end{array}$ & $\begin{array}{r}\$ 20.00 \\
16.00\end{array}$ \\
\hline COLLECTION No. 3 & $\begin{array}{l}\text { 3-5 eye } \\
\text { Div. }\end{array}$ & $1-Y r$. & COLLECTION No. 4 & $\begin{array}{c}\text { 3-5 eye } \\
\text { Div. }\end{array}$ & 1 - Yr. \\
\hline 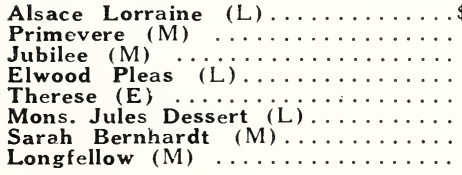 & $\begin{array}{l}1.75 \\
2.00 \\
1.50 \\
2.50 \\
2.50 \\
2.00 \\
1.50 \\
2.50\end{array}$ & $\begin{array}{l}\$ 2.00 \\
3.00 \\
2.00 \\
3.00 \\
3.00 \\
3.00 \\
2.00 \\
3.50\end{array}$ & 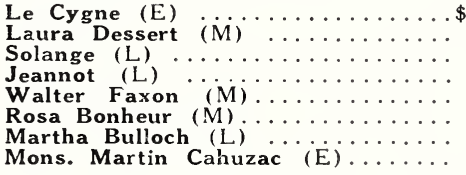 & $\begin{array}{l}6.00 \\
4.00 \\
2.50 \\
5.00 \\
3.00 \\
2.50 \\
5.00 \\
2.00\end{array}$ & $\begin{array}{l}\$ 8.00 \\
6.00 \\
3.50 \\
6.00 \\
4.00 \\
3.50 \\
6.00 \\
2.50\end{array}$ \\
\hline$\ldots \ldots \ldots$ & $\begin{array}{l}\$ 16 \\
14\end{array}$ & 19.50 & Net Price & $\begin{array}{r}30.00 \\
27.00\end{array}$ & $\begin{array}{r}\$ 39.50 \\
35.00\end{array}$ \\
\hline
\end{tabular}




\section{Japanese Iris} Flowers six to ren inches in drameter, will grow in almost any so:l that does not become

The best time to plant is July, and from that on until the middle of September the plants may be sarely planted in localities not too far north. so tha they may have time to establis tanted rather late. cold weather sets in. If they are planted rather late they should be freety mulched atter the ground is frozen in ate autumn to seep the ground from heav ing.

Vake cut your order for Japanese Iris and de thot is, for orders between $\$ 10$ and 573 For $\$ 2 j$ and up. deduct 25

Vet Price of Mixture: $\$ 1.50$ per $10 ; \$ 10$ per 100 .

3. Betty Jean Childs. Single. White Eaintly splash ed and veinef with orchid. petaloids deepe shade 60 cts: 3 at $5 j$ cts. each.

Catherine Parry. Double. Blue overlaid with rosy-red. High tutts in center.

- More 30 cts. each. Durple suffused with violet. slichty veined with white. Beautiful golden center radiating into lines. Very tall, strong grower abundant bloomer. 6. Eleanor Parry Double. Clarer red. Aamed white and blue. tedim size.

- Frances 5 Cleveland. Semi-double. Very large

10. Datedogus. Single. Vert large fowers. Claret red with orange blotches, surrounded by a halo of blue radiating into heavy lines. Stand. ards light claret and white. jo cts.: at 4 jots. each. Violet purple veined

12. Bhite. 27 cts 3 or more at 20 cts each 12. Blue jay.

14. Shishi-Ikari. White ground. reined with dark

15. Gekha-No-Nami. Syn. Gold Bound). Pure wherish blotches: petaloid stigmas: six petals 50 cents.: 3 or more at 45 cts. each.

16. Kumo-Ma-No-Sora. Immense white crepy petals with a delicate sky blue halo overlaring a por-

40. Margare: S. Hendrickson. Triple. Large wavy petals of soft bluish violet. Cast of blie ra

43. Purple, overlaid with navy blue. two standards: petaloid stigmas purple and blue: large orange blotches: six petals. Late - cts.; 3 or Amethyst. Single Very large. wavy petals most exquisite lavender shade. jo cts.; of

Maho any

Double. Dar. Dot

46. Vorma. Double. Exquisite silky lavender-pink with clear blue halo surrounding the yellow

49. Red Riding Hood. Single. Gine amarinth vein

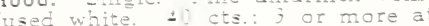

51. Sho-Jo. ithite heawit veined violet: three

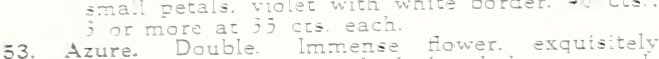

wavy mave-blue with darker halo surround-

54. Sufo-Vo-ko cts Double more at color blotched and speckied blue and white with yellow throat; stanens lavender tipped blue.

55. Blue Bird. Singe Deep velvet blue. 50 cts

56. Kumo-No-Obi. Double, Sxy blue petals lined

53. Nomo-opi-notahi. Douole Bright crimson. white halo surrounding yelow olotches: pat

C5. Ho-Ojo. Ruddy crimson primrose blotches with purple: six petals 4 cts: 3 or more at

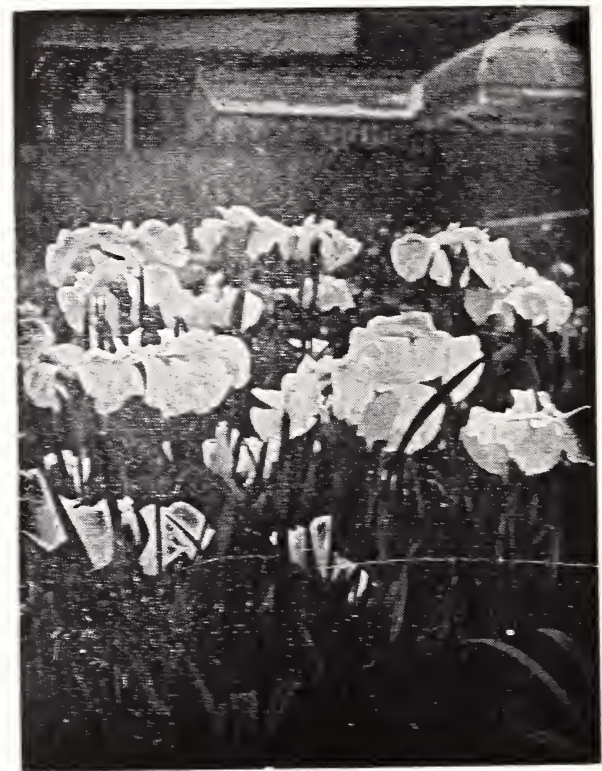

JAPANESE IRIS

67. White, medium height; three large petals; three small petals; late 40 cts.; 3 or more at

71. Pyramid. Double Dark violet blue. slightly reined white; very fine. Last to bloom. 25 cts. or more at 20 cts.; $\$ 15$ per 100 .

72. Double, rich deep purple with yellow blotches

7. Pinl cts: 3 or more at 20 cts. each. ink Progress. Single. Ashy-grey lavender clear olue halo overiaid with

75. Kamata. Single. Deepest sky-blue, veined whistinct 20 cts: 3 or more at

76. Mirage. Single. Light pink, suffused with light blue towards the center. 30 cts.; 3 or more

so. Alida Lovett. Double. Very heavily veined Alida hovett. Double. lavender blue on

52. Templeton. Double. Light violet mottled pink 3 or more at 45 cts. each. Q3. Totty's Irue Blue. Double. Dark violet blue 100. Ruffled Monster. Double, deep pinkish plum heavily veined white surrounding the yellow heavil feined whith formed and beautiful. rufled. very large and striking ij cts. each: 3 for

\section{VARIOUS IRISES}

Sibirica. Siberian. Flag). Two to three beet high, with narrow grassy leaves: show blue rowers. $\$ 1.50$ per ten.

Siberica Emperor. Dark violet blue Largest per 10.

Siberica Perry's Blue. A large flower of clear blue ith horizontal rail probably the rnest s.berican

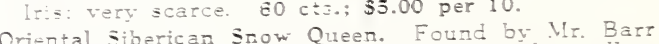
in Japan. Pure. glistening white with yellow Proia in addition to making fine edgings for borHars tis species and its varieties are excellent for rock gardens. They are very dwarf and bloom Pumila Lutea. 25 cts.; $\$ 2.00$ per 10.

Pumila Bride. lvory white.

Pumila Cyanea. Bcautiful deep blue.

Cristatu. Crested Iris A gem for rock garden. $25 \mathrm{cts}$. 


\section{S. G. HARRIS, TARRYTOWN, N. Y.}

The use of this Order Sheet will insure the

prompt and correct filling of your order of not less than $\$ 3.00$

Date sent

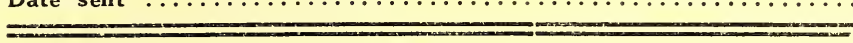

Please Do Not Write Here

City

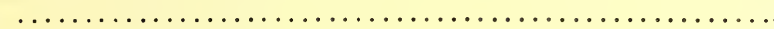

Street

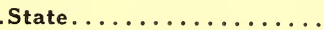

Express Address

(if different from $P$. O.)

Via

Ship about.

AMOUNT

ENCLOSED

No.

Rec'd.

Shipped

...................... 1928

DOUBLE VARIETIES

ADOLPHE ROUSSEAU

I ALBA SULPHUREA

ALBATRE

ALBERT CROUSSE

| ALFRED DE MUSSET

ALSACE-LORRAINE

ARMANDINE MECHIN

ASA GRAY

A.UGUSTIN D'HOUR

I AURORE

AVALANCHE

BARONESS SCHROEDER

BOULE DE NEIGE:

CANARI

CARNEA ELEGANS

CHERRY HILL

CLAIRE DUBOIS

COURONNE D'OR

DE CANDOLLE

DELACHEI

DORCHESTER

| DOCTEUR BRETONNEAU (Guerin)

DUC DE WELLINGTON

DUCHESS DE NEMOURS

EDULIS SUPERBA

I ELWOOD PLEAS

I EUGENE BIGOT

I EUGENE VERDIER

EUGENIE VERDIER

FELIX CROUSSE

| FESTIVA

| FESTIVA MAXIMA

FRANCES WILLARD

GALATHEE

GENERAL BERTRAND

GERMAINE BIGOT

GISMONDA

GLOIRE DE CHAS. GOMBAULT

I GLOIRE DE CHAS. COMBAULT

By

\begin{tabular}{|c|c|c|c|}
\hline $\begin{array}{l}3-5 \\
\text { Eye } \\
\text { Div. }\end{array}$ & $1-Y r$. & $\begin{array}{l}\text { 2-Yr. } \\
\$\end{array}$ & \\
\hline$\$ 1.50$ & $\$ 2.00$ & & | \\
\hline .75 & 1.00 & 1.50 & \\
\hline .75 & 1.00 & 1.50 & \\
\hline .75 & 1.00 & 1.50 & \\
\hline .75 & 1.00 & 1.50 & \\
\hline 1.75 & 2.00 & & 1 \\
\hline .50 & .75 & 1.00 & \\
\hline 1.00 & 1.25 & 2.00 & \\
\hline .75 & 1.00 & 1.50 & \\
\hline .75 & 1.00 & 1.50 & \\
\hline .75 & 1.00 & 1.50 & \\
\hline 1.00 & 1.50 & 2.25 & \\
\hline .50 & .75 & 1.25 & \\
\hline .50 & .75 & & I \\
\hline .75 & 1.00 & & 1 \\
\hline 3.50 & 4.50 & & I \\
\hline 1.00 & 1.25 & 2.00 & \\
\hline .75 & 1.00 & 1.50 & \\
\hline .50 & .75 & 1.25 & \\
\hline .75 & 1.00 & & \\
\hline .75 & & 1.25 & \\
\hline .50 & & 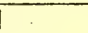 & I \\
\hline .50 & .75 & & 1 \\
\hline .50 & .75 & & \\
\hline .50 & .75 & 1.25 & \\
\hline 2.50 & 3.00 & & \\
\hline 1.50 & 2.00 & & I \\
\hline 1.50 & 2.00 & 3.00 & I \\
\hline 1.00 & & 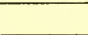 & $T$ \\
\hline .75 & 1.00 & 1.50 & \\
\hline .50 & .75 & 1.00 & \\
\hline .50 & .75 & 1.25 & \\
\hline 1.50 & 2.00 & & \\
\hline 3.00 & 3.50 & & \\
\hline .50 & .75 & 1.00 & \\
\hline .75 & 1.25 & 2.00 & \\
\hline 1.00 & 1.50 & 2.00 & \\
\hline 1.00 & 1.50 & 2.00 & \\
\hline & & & \\
\hline & & 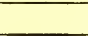 & \\
\hline & & 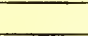 & \\
\hline & & & \\
\hline
\end{tabular}




\begin{tabular}{|c|c|}
\hline GRANDIFLORA & $\$$ \\
\hline GRANDIFLORA NIVEA PLENA & I \\
\hline HENRY AVERY & 3 \\
\hline JAMES KELWAY & 1 \\
\hline JEANNE D'ARC & \\
\hline JEANNOT & 5 \\
\hline JUBILEE & 1 \\
\hline KARL ROSENFIELD & 1 \\
\hline KELWAY'S GLORIOUS & 8 \\
\hline LADY ALEXANDRA DUFF & 12 \\
\hline LA FIANCEE & 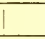 \\
\hline LA FRANCE & ! \\
\hline LA LORRAINE & 5 \\
\hline LAMARTINE & i \\
\hline
\end{tabular}

\begin{tabular}{|c|c|c|}
\hline $\begin{array}{l}3-5 \\
\text { Eye } \\
\text { Div. }\end{array}$ & $1-Y r$ & $\underset{\$}{2-Y r .}$ \\
\hline$\$ .75$ & $\$ 1.00$ & 2.00 \\
\hline .50 & .75 & 1.00 \\
\hline 3.00 & 3.50 & \\
\hline 1.00 & 1.50 & 2.25 \\
\hline .75 & 1.00 & 1.50 \\
\hline 5.00 & 6.00 & \\
\hline 1.50 & 2.00 & 3.00 \\
\hline .75 & 1.00 & 1.50 \\
\hline 8.00 & 10.00 & \\
\hline 2.00 & 2.50 & \\
\hline .75 & & \\
\hline 3.00 & 4.00 & \\
\hline 5.00 & & \\
\hline .75 & 1.50 & 2.25 \\
\hline & 1.00 & \\
\hline .75 & 1.00 & \\
\hline .75 & 1.00 & 1.50 \\
\hline 4.00 & & \\
\hline 7.00 & 9.00 & \\
\hline .75 & 1.00 & \\
\hline 2.50 & 3.50 & \\
\hline & 1.50 & \\
\hline 1.00 & 1.50 & \\
\hline .50 & .75 & 1.00 \\
\hline .75 & 1.00 & 1.50 \\
\hline .50 & .75 & 1.00 \\
\hline .50 & .75 & 1.00 \\
\hline .50 & .75 & 1.00 \\
\hline .50 & .75 & 1.00 \\
\hline .50 & .75 & 1.00 \\
\hline .50 & .75 & 1.00 \\
\hline .50 & 1.00 & 1.50 \\
\hline 1.00 & 1.50 & \\
\hline \begin{tabular}{|l|}
1.00 \\
\end{tabular} & 1.50 & I \\
\hline 2.00 & 3.00 & | \\
\hline .75 & 1.00 & 1.50 \\
\hline 2.50 & 3.50 & \\
\hline .75 & & 1.25 \\
\hline .75 & 1.00 & 1.50 \\
\hline .50 & .75 & 1.00 \\
\hline .75 & & 11.50 \\
\hline 1.00 & 1.50 & 2.00 \\
\hline .75 & 11.00 & $1 \quad 1.50$ \\
\hline 1.00 & 1.50 & 2.00 \\
\hline .75 & 1.00 & 1.50 \\
\hline .75 & 1.00 & 1.50 \\
\hline 5.00 & 6.00 & \\
\hline $\begin{array}{r}\mathbf{5} .00 \\
\end{array}$ & 6.00 & \\
\hline 3.00 & 4.00 & 5.00 \\
\hline .75 & & \\
\hline .75 & & \\
\hline 1.00 & 1.50 & 2.00 \\
\hline $\begin{array}{l}2.00 \\
\end{array}$ & 2.50 & \\
\hline 12.00 & & I \\
\hline
\end{tabular}

LA PERLE

LA TENDRESSE

LAURA DESSERT

I LE CYGNE

LIVINGSTONE

LONGFELLOW

LORD KITCHENER

MME. AUGUSTE DESSERT

MME. BOLLET

MME. BUCQUET

MME. CHAUMY

MME. CALOT

MME. CROUSSE

MME. DE GALHOU

MME. DE VATRY

MME. DE VERNEVILLE

MME. DUCEL

MME. EMILE GALLE

MNE. EMILE LEMOINE

MME. JUIES DESSERT

MME. LEMONIER

MME. GAUDICHAU

MME. REIGNOUX

MLLE. LEONIE CALOT

MLLE. MARIE CALOT

MLLE. ROUSSEAU

MARCELLE DESSERT

MARGUERITE GERARD

MARIE CROUSSE

MARIE JACQUIN

MARIE LEMOINE

I MARTHA BULLOCH

MARY WOODBURY SHAYLOR

MILTON HILL

MODESTE GUERIN

MONS. DUPONT

I MONS. JULES ELIE

I MONS. MARTIN CAHUZAC

NRS. EDWARD HARDING 
NUMBER ONE

OCTAVIE DEMAY

OFFICINALIS RUBRA

PETITE RENEE

PHILOMELE

PHILLIPE RIVOIRE

PIERRE DESSERT

PIERRE DUCHARTRE

PRIMEVERE

PRINCE DE TALINDYKE

RAOUL DESSERT

RAPHAEL

REINE HORTENSE

RICHARD CARVEL

ROSA BONHEUR

RUBRA SUPERBA

SARAH BERNHARDT

SOLANGE

SOUV. DE LOUIS BIGOT

THERESE

TOURANGELLE

I TRIOMPHE DE LILLE

UMBELLATA ROSEA

VENUS

I VILLE DE NANCY

WALTER FAXON

SINGIA AND JAPANESE VARIRTIES

\begin{tabular}{|c|c|c|c|c|}
\hline AMA-NO-SODE & I & 8.00 & 10.00 & \\
\hline CARNOT & 1 & 1.00 & 1.50 & \\
\hline DARKNESS & $!$ & 1.00 & 1.50 & \\
\hline CLAIRETTE & I & 2.00 & 2.50 & \\
\hline EGLANTINE & I & 2.00 & 3.00 & \\
\hline EMILY & 1 & 1.00 & 1.50 & \\
\hline FESTIVA FRAGRANS & I & .75 & 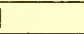 & 1.50 \\
\hline FUYAJO & 1 & 6.00 & 7.00 & \\
\hline HERMES & 1 & .50 & .75 & \\
\hline ISANI-GIDUI & I & 8.00 & 10.00 & \\
\hline KINO-KIMO & 1 & 1.50 & 2.00 & \\
\hline LA FIANCEE & I & 1.75 & 2.25 & \\
\hline LE JOUR & 1 & 3.50 & 4.50 & \\
\hline | L'ETINCELANTE & I & 1.50 & 2.00 & 3.00 \\
\hline LEMON QUEEN & I & 1.00 & 1.50 & \\
\hline LUCIENNE & 1 & 1.00 & 1.50 & \\
\hline I MARGUERITE DESSERT & 1 & 3.00 & 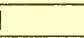 & \\
\hline MIKADO & 1 & 2.00 & 2.50 & \\
\hline I MADELINE GAUTHIER & 1 & 2.00 & 2.50 & \\
\hline I NUMBER 1001 & 1 & ! & 2.50 & \\
\hline I PRIDE OF LANGPORT & 1 & 4.50 & 5.50 & \\
\hline I QUEEN OF MAY & 1 & .75 & 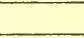 & 2.00 \\
\hline ROSY DAWN & $!$ & 1.00 & 1.50 & \\
\hline I SNOW WHEEL & 1 & 2.00 & 3.00 & \\
\hline SOME GANOKO & 1 & 4.00 & 5.00 & \\
\hline TAMATBAKO & 1 & 17.50 & 20.00 & \\
\hline THE MOOR & $!$ & 1.00 & 1.50 & \\
\hline TOKIO & 1 & 4.00 & 5.00 & \\
\hline I VELOUTINE & 1 & 1.50 & 2.00 & \\
\hline I VENISE & 1 & 1 & 2.00 & \\
\hline I WHITLEYI MAJOR & 1 & 1.50 & 2.00 & \\
\hline YESO & 1 & 1.50 & 2.00 & \\
\hline I YOUCHINATSUKI & 1 & 2.00 & 1 & \\
\hline 1 & $!$ & 1 & 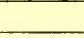 & \\
\hline 1 & 1 & 1 & 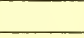 & \\
\hline & $T$ & $!$ & 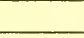 & \\
\hline
\end{tabular}

2.25

1.50

\begin{tabular}{r|r|r|}
.75 & 1.00 & 1.50 \\
\hline 1.00 & 1.50 & 2.25
\end{tabular}

\begin{tabular}{l|l|l|l|}
.75 & 1.00 & 1.50
\end{tabular}

7.50

\begin{tabular}{l|l|}
.75 & 1.00 \\
\hline
\end{tabular}

\begin{tabular}{l|l|l|l|}
\hline 2.00 & 3.00 & 4.00
\end{tabular}

\begin{tabular}{l|l|}
.75 & 1.00
\end{tabular}

\begin{tabular}{l|l|l|}
5.00 & 6.00
\end{tabular}

\begin{tabular}{l|l|}
.75 & 1.00
\end{tabular}

$1.00|1.50| 2.00$

$3.00 \mid 4.00$

2.50

.75

1.50

2.50

3.50

2.50

2.00

.50

.50

.75

.50

3.00

\begin{tabular}{l|l|}
3.50 & 4.00
\end{tabular}

1.00

\begin{tabular}{l|l|}
2.00 & 3.00
\end{tabular}

3.50

4.50

\begin{tabular}{l|l|l|}
3.00 & 4.50
\end{tabular}

2.50

\begin{tabular}{l|l|}
.75 & 1.25
\end{tabular}

1.00

.75

4.00

0

2-Yr.

I

1

$\frac{1}{1}$

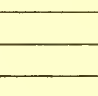




\section{OTHER PLANTS}




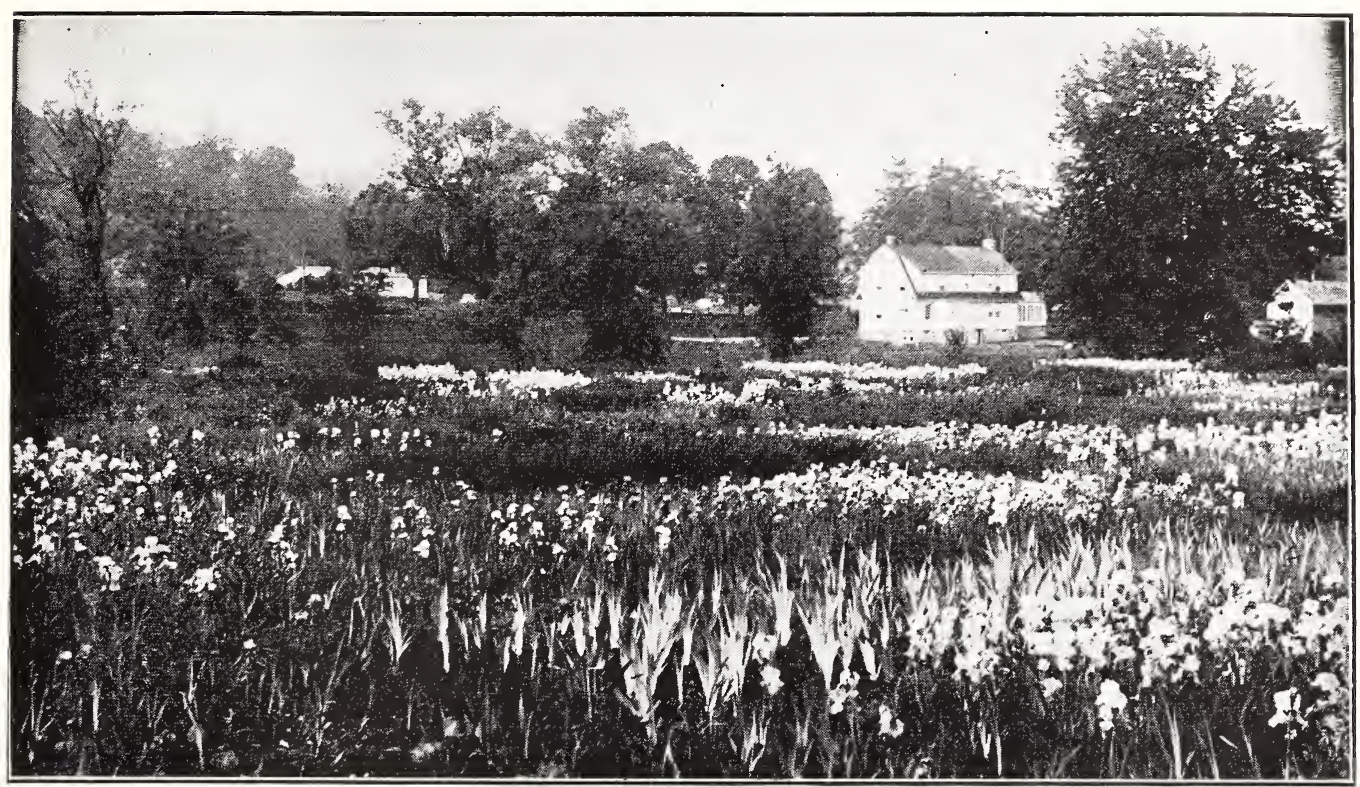

A PART OF OUR BEARDED IRIS

Our stock of German lris has never been more complete and extensive, and 1 know of no place where the prices of those large growing varieties, in the Pallida Section particularly, are offered at such a low rate. Such varieties as Pallida Speciosa, three to four feet tall, we are pricing at 10 c each where 25 or more are ordered.

Figures before descriptions are rating by American lris Society.

\section{SPECIAL OFFER}

Owing to the extensive stock of the following varieties we are making a special offer in lots of 100 to 500 , not less than 10 of a variety, $\$ 10.00$ per 100

$\begin{array}{ll}\text { Dorothea } & \text { Fairy } \\ \text { Loreley } & \text { Darius } \\ \text { Mrs. H. Darwin } & \text { Mme. Chereau } \\ \text { Pall. Speciosa } & \text { Queen Alexandra } \\ \text { Pall. Juniata } & \end{array}$

\section{DISCOUNTS}

Make out your order for Bearded lris and deduct from the total $15 \%$ for orders between $\$ 10$ and $\$ 25$. For $\$ 25$ and up deduct $25 \%$

Net Price of Mixture: $\$ 1.00$ per $10 ; \$ 5$ per 100 .

The German lrises are all sun lovers and thrive best in warm, fertile, well-drained soils. Their roots lie near the surface of the ground and require the warming, baking rays of the sun. They will thrive on almost any kind of soil except one that is con tinuously wet.

\section{CULTURE OF GERMAN IRIS}

As the flower buds are formed in late summer or fall the best time for planting is mid-summer. If planted in the spring the flower buds will either blight or stunt; if planted too late in the summer they may not have sufficient time to root in and prepare for a spring blooming period. The best time, there fore, is when they are most dormant, in the summer during July and early August, although they may be planted anytime without jeopardizing their lives.

Few of our cultivated plants are capable of giving as much in return for so little care and attention as are the Bearded lris. Many of the newer ones and some of the older ones are perfect gems of the flower world. Nor do they need any petting; only a spot in the sun that may be called their own and at intervals every few years a little thinning out. What more could the garden lover ask? Any soil that would grow corn or is reasonably well drained will answer. If the soil is too poor to grow the prize winning blooms you would like to produce, it is profitable to work into it some bonemeal before planting and to give a light annual dressing, but it is safest to use no other fertilizer of any kind.

The following abbreviations are used: $S$ means standards or upper petals; $F$ means falls or lower petals.

8.6. Afterglow. Misty lavender red with yellow at the center. 50 cts.; 3 for $\$ 1.25$.

8.9. Alcazar. $S$ light bluish violet; $F$ brilliant pur ple, Orange beard. Stout. 44 in. 35 cts.; 3 for 85 cts.; 10 for $\$ 2.50$.

9.4. Ambassadeur. S smoky, reddish violet; $F$ dark, velvety purple-maroon. Tall, straight, strong stems. Late. 75 cts. each; 3 for $\$ 2.00$.

8.3. Archeveque. $S$ deep purple violet; $F$ velvety red purple. Very rich color and large flow. ers. $35 \mathrm{cts}$.; 3 for 85 cts.;10 for $\$ 2.50$.

9.4. Ballerine. $S$ waved at the margin with light blue violet; $F$ deep blue; sweet scented; large size. 48 in. $\$ 1.00$.

7.7. Black Prince. (Not the English.) Earliest rich, dark purple. 2 feet. 25 cts.; 50 cts. for $3 ; 10$ for $\$ 1.50$.

8.5. B. Y Morrison. S pale lavender violet; $F$ vel vety purple with white lavender border. $\mathbf{7 5}$ cts.; 3 for $\$ \mathbf{2 . 0 0}$

7.5. Caprice. S rosy red; $F$ deeper rosy red, beard yellow. Handsome, 2 feet. 25 cts.; 50 cts. for $3 ; 10$ for $\$ 1.50$.

7.1. Celeste. Pale azure blue. 30 inches. 25 cts.; 3 for 50 cts.; 10 for $\$ 1.50$.

Col. Corwin. Rich plum. 30 inches. 25 cts. 3 for 50 cts.; 10 for $\$ 1.50$.

7.1. Common Purple. Purple One of the best. 30

in. 25 cts.; 3 for 60 cts.; 10 for 1.50

8.7. Crusader. S light blue violet; $F$ deep shade of violet. Large flowers on tall stems. 75 cts.; 3 for $\$ 2.00$

8.7. Cypriana. S lavender violet; $F$ drooping, hyacinth violet. 50 cts.; 3 for $\$ 1.25$.

6.8. Darius. S rich canary-yellow; $F$ lilac, margined white; rich orange beard; one of the most distinct and beautiful. 20 inches. 25 cts. 3 for $50 \mathrm{cts}$.; 10 for $\$ 1.50$

7.6. Dorothea. Shallow gray marked with white, tinged lilac. 25 cts. each; 3 for 50 cents; 10 for $\$ 1.50$. 
7.8. Eldorado. S fiery opalescent; $F$ old gold silhouetted with purple, a totally distinct harmony of striking hues, perfectly blended. mony of striking hues, perfectly blended. cts.; 10 for $\$ 2.50$.

8.0. Fairy. White, delicately bordered and suffused soft blue. Very fragrant. 30 in. 25 cts.; 3 for 50 cts.; 10 for $\$ 1.50$.

7.6. Florentina Alba. Creamy-white, faintly flushed lavender; the blooms are quite fragrant. feet. 25 cts.; 3 for 50 cts.; 10 for $\$ 1.50$

6.1. Gracchus. S lemon yellow, with tinge of primrose; $F$ nearly crimson with red purple tracings. Early. 25 cts.; 3 for 60 cts.; 10 for $\$ 1.50$.

7.7. Ingeborg. Pure white. Large flowers of handsome form. 25 cts.; 3 for $€ 0$ cts.; 10 for $\$ 1.50$.

7.9. Iris King. S old gold; $F$ very large velvety maroon, edged with gold. Well named "The King of the lris." 28 in. 35 cts.; 3 for 70 cts.; 10 for $\$ 2.00$.

8.0. Jacquesiana. S bright coppery crimson; $F$ rich maroon: very handsome. Scarce. 30 in. 35 cts.; 3 for 85 cts.; 10 for $\$ 2.50$

7.3. Jeanne d'Arc. S white, penciled lilac; $F$ white bordered lilac at base. 25 cts.; 3 for 60 cts.; 10 for $\$ 1.50$.

7.4. Kharput. S violet; $F$ velvety purple. Very large handsome flower. 30 inches. 25 cts.; 3 for $60 \mathrm{cis}$; 10 for $\$ 1.50$.

7.3. Kochii. (Syn Atropurpurea). $S$ and $F$ rich claret-purple. Often sold under the name of Black Prince. 15 inches. 25 cts.; 3 for 60 cts.; 10 for $\$ 1.50$.

9.0. Lent A. Williamson. S lavender violet; $F$ velvety royal purple. A massive flower of high standard. $50 \mathrm{cts}$.; 3 for $\$ 1.25$.

9.1. Lord of June. S light chickory blue; $F$ lavender violet. Said to be one of the world's finest Irises. 50 cts.; 3 for $\$ 1.25$.

7.9. Loreley. $S$ light yellow; F ultra marine, bordered with cream. 28 inches. 25 cts.; 3 for 50 cts.; 10 for $\$ 1.50$.

7.4. Madame Chereau. White elegantly frilled with a wide border of clear blue; one of the most
beautiful. 31 inches. 25 cts.; 3 for 50 cts.; 10 for $\$ 1.50$.

8.1. Ma Mie. S pure white, frilled light violet; $F$ white, penciled and margined lavender and veined green. Beautiful and compact. 35 cts.; 3 for 85 cts.; 10 for $\$ 2.50$.

7.8. Mary Garden. S pale yellow flushed pale lavender; $F$ creamy white minutely dotted and veined maroon; stigma clear yellow. An elegant flower of distinct iridescent effect. 28 inches. 35 cts.; 3 for 85 cts.; 10 for $\$ 2.50$.

Mary Orth. S light blue violet; $F$ dark blue violet. One of Farr's best. 24 in. \$1.00; 3 for $\$ 2.50$.

Mildred Presby. S white; F rich dark purple. Very choice, best of its type. 30 in. $\$ 2.00$; 3 for $\$ 5.00$.

8.4. Monsignor. S rich satiny violet; $F$ velvety purple crimson with lighter margin. Large cts.; 3 for 50 cts.; 10 for $\$ 1.50$.

Mother of Fearl. $S$ and $F$ pale bluish lavender with a faint creamy undertone. Large flow. ers with a cluster and iridescent similar to the lining of the sea shell. 40 in. 50 cts.; 3 for $\$ 1.25$.

6.8. Mrs. H. Darwin. 30 in. Late. S pure white; $F$ white, finely reticulated. One of the most charming whites. 25 cts.; 3 for 60 cts.; 10 for $\$ 1.50$.

6.8. Mrs, Neubrunner. Deep golden-yellow; darker than Aurea. 25 cts.; 3 for 60 cts.; 10 for $\$ 1.50$.

7.3. Nibelungen. S fawn-yellow; $F$ violet purple on bronze. Very large. 25 cts.; 3 for 60 cts.; 10 for $\$ 1.50$.

8.1. Parc de Neuiliy. $S$ and $F$ very dark navy-blue of reddich tinge. Large flowers of perfect form. 35 cts.; 3 for 85 cts.; 10 for $\$ 2.50$.

7.9. Parisiana. $S$ deep lavender, with some white on the inner side; F white beautifully lined and tinted with lavender, matching the standards. 35 cts.; 3 for 85 cts.; 10 for $\$ 2.50$.
7.8. Perfection. $S$ light lavender; $F$ velvety black violet. 25 cts.; 3 for 60 cts.; 10 for $\$ 1.50$.

7.7. Pocahontas. Pure white, faintly bordered pale blue. 35 cts.; 3 for 85 cts.; 10 for $\$ 2.50$.

8.3. Prosper Laugier." S light bronze-red; F velvety ruby-purple, with orange beard. Very hand some. $35 \mathrm{cts}$; 3 for 85 cts.; 10 for $\$ 2.50$.

8.4. Quaker Lady. S smoky lavender with yellow shadings; $F$ ageratim-blue and old gold, with Its distinguishin name is most suitable. 38 in. 35 cts.; 3 for 60 cts.; 10 for $\$ 1.50$.

7.5. Queen Alexandra.; S fawn, shot with lilac; F lilac, reticulated bronze at base. Beard yellow. Very beautiful. 30 inches. 25 cts.; 3 for 60 cts.; 10 for $\$ 1.50$.

9.0. Queen Caterina. Pale lavender with smooth, iridescent sheen; strong, erect stems. Free and reliable bloomer. One of the finest Iris. 75 cts. each; 3 for $\$ 2.00$.

8.4. Rhein Nixe. S pure white; F deep violet blue, with a white edge. A great favorite. Equal to many of the newer introductions. 3 feet. 35 cts.; 3 for 85 cts.; 10 for $\$ 2.50$.

6.9. Rose Unique. Bright violet rose. Nearest approach to a pink lris. Early. 35 cts.; 3 for 70 cts.; 10 for $\$ 2.50$.

8.3. Seminole. $S$ white; F white, faintly shaded blue with network of blue lines. Vigorous grower. $50 \mathrm{cts}$. each; 3 for $\$ 1.25$

9.3. Souvenir de Mme. Gaudichau. Very large deep purple bicolor. Rich velvety petals. S broad, violet; F drooping brilliant velvety
blackish purple. Over 3 feet. $\$ 1.00 ; 3$ for
$\$ 2.50$

8.8. Shekinah. The first good yellow of Pallida type and growth. Ciood size, graceful flower with both $\mathrm{S}$ and $\mathrm{F}$ pinard-yellow. Vigorous plant with high and widely branched stalks. 3 feet. 50 cts. 3 for $\$ 1.0$ ranched stalks.

6.5. Victorine. S mottled blue; $\dot{F}$ violet blue, mottled white. 27 in. 25 cts.; 3 for 50 cts.; 10 for $\$ 1.50$.

7.3. Windham. S delicate lilac; $F$ white striped with lavender. Much of the appearance of Her Majesty. Good "pink." 24 in. 25 cts.; 3 for 50 cts.; 10 for $\$ 1.50$

7.2. Wyomissing. S creamy white suffused delicate soft rose; F deep rose base, shading to flesh-
colored border. 35 cts.; 3 for 70 cts.; 10 for $\$ 2.50$.

7.5. Zua. $S$ and $F$ white, slightly tinged lilac; texture like heavily frosted crepe, with edges crimpled and crinkled, immense flowers, free bloomer. Very fragrant. 50 cts.; 3 for $\$ 1.25 ; 10$ for $\$ 3.50$.

\section{PALLIDA SECTION}

7.9. Albert Victor. $S$ soft blue; $F$ beautiful lavender; large and fine. 40 inches. 25 cts.; 3 for 60 cts.; 10 for $\$ 1.50$

8.8. Dalmatica. S lavender: $F$ clear deep lavender Howers very large. extra fine. A grand variety for massing and for cut flowers. 40 inches. 35 cts.; 3 for 85 cts.; 10 for $\$ 2.50$.

5.0. Garibaldi. Similar to Her Majesty, but deepe

pink. $25 \mathrm{cts}$; 3 for $60 \mathrm{cts}$; 10 for $\$ 1.50$. tinged a darker shade. 35 cts.; 3 for 70 cts.; 10 for $\$ 2.00$.

8.1. Juniata matica. Tallest of all the bearded lrises; foliage long and drooping; flowers large and fragrant. 35 cts.; 3 for 60 cts.; 10 for $\$ 1.50$.

8.2. Lohengrin (Pallida). $\mathrm{S}$ and $\mathrm{F}$. soft silvery mauve, shading nearly to white at the claw. 33 inches. 30 cts.; 3 for 75 cts.; 10 for $\$ 2.00$.

8.0. Powhatan. S light bishop-violet with deeper border; F deep purple shaded crimson; large, horizontal spreading flower. 50 cts.; 3 for $\$ 1.25$.

6.3. Speciosa. $S$ dark lavender, shaded lighter; $F$ lavender, shaded bright purple. 42 inches. 25 cts.; 3 for 60 cts.; 10 for $\$ 1.50$.

A plant ready for planting consists of 3 essential parts-the leaves, the rhizome (often mistakenly called bulb), and the roots. Drying does not injure the leaves or rhizomes, but kills the roots. See that they do not dry out; if the soil is dry at planting time, fill the trench or hole with water and after it has soaked into the ground, spread the roots over the moist surface and draw soil over them, tramping it down firmly and covering with loose soil. The rhizome should be just below or at the surface and should be held firmly in place if the soil has been properly packed over the roots. 
Are you planning a hardy flower garden or perinnial border? Use plenty of Peonies, Iris and Phlox. These will give continuous bloom from May 15 to October 15; first, the bearded Iris, May and early June, followed by Peonies in June, Japanese 1 is in July and Phlox, July, August and September. Interspersed among them may be used colonies of Aquilegia, Digitalis, Delphinium and other favorites in beautiful color combinations to suit ones taste.

\section{PHLOX}

Following the lris and Peonies in time of bloom, but in no way behind them in popularity, are the Hardy Perennial Phloxes. We have weeded out all the magentas and purples and believe that our list is as select as that offered by any firm.

1 -year blooming size, $30 \mathrm{cts}$. each; $\$ 2.50$ per ten 2 -year heavy, 35 cts. each; $\$ 3.00$ per ten. Five at ten rate, provided not less than five of a kind are ordered.

\section{Culture of Phlox}

Phlox are shallow rooted plants and should there fore be planted a little deeper than most other plant ings and kept well tilled to conserve the moisture, as they cannot stand dry packed soil like Peonies and Iris. No fertilizer should be near the roots. A little bonemeal sprinkled on the surface of the ground be fore hoeing gives good results, but be careful not fore hoeing gives

Baron Comte. Satiny purple.

Baron Von Dedem. Blood red.

Bridesmaid. Large, white with crimson center.

Elizabeth Campbell. Very bright salmon-pink, with

lighter shadings and dark red eye; one of the handsomest. 35 cts.; $\$ 3.00$ per ten. Blooming size only.

Europe. White with decided crimson-carmine eye individual trusses and flowers very large; sturdy, erect habit.

Independence. Large, pure white.

Lothair. Large; rosy salmon, with crimson eye.

Mme. Bezanson. Deep red.

Miss Lingard. Blooms in May, fully six weeks earlier than the other sorts, and continues in bloom three months; a grand white variety, which should be in every collection.

Mirs. E. J. Norman. Delicate blush pink; strong grower, and free bloomer, with petals of great substance.

Peachblow. Delicate pink, deep rose center; rather dwarf-habit, splendid trusses. Superb.

Queen. Pure white. One of the best. Tall.

Rhinelander. A beautiful salmon pink.

Rynstrom. A grand new Phlox, resembling Pantheon, but with larger flower heads; a soft clear pink, medium height and strong grower.

R. P. Struthers. Bright rosy-red; crimson eye.

Sir Edward Landseer. Flower bright crimson.

Thor. A most beautiful and lovely shade of deep salmon-pink, suffused and overlaid with a scarlet glow.

Von Lassburg. Purest white, individual flowers very large.
Our spring, 1928 catalog listing choicest varieties of fruit and ornamental trees, shrub; and flowering Evergreens and many cultural direchions for the planter will be sent on application.

\section{HARDY PERENNIALS}

All our Perennials are strong field grown; please note that with the exception of the lris and Peonies, we are offering Perennials in quantities of three instead of singly. As it takes little longer to label and wrap three of a kind instead of one, I believe we could handle small quantities at the present prices without a loss. Owing to the very favorable season all our Perennials have done exceedingly well and the sizes will run larger than our usual large sizes.

5 plants of a kind will be priced at the 10 rate.

Make out your order for these Perennials and deduct $20 \%$, our removal sale discount.

Astilbe (Spiraea).

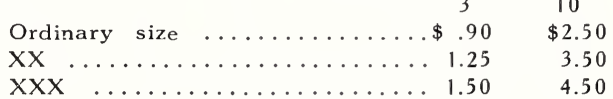

Queen Alexandra (Pink).

Peach Blossom (Pink).

Palmata (Tall), (Pink).

Gladstone (White).

Floribunda (White).

Convallaria (Lily of the Valley).

Heavy Clumps ............. 1.25 3.50

Ordinary Clumps ............90 $90 \quad 2.50$

Hibiscus (Mallow Marvels)...... $.90 \quad 2.50$

Hemerocallis (Yellow Day Lily)..... .90 2.50

Aurantiaca Major (June).

Flava (May).

Kwanso-Double (July).

Thunbergii-Lemon Lily (July).

Hosta (Funkia), XX........... .90

Yucca (Adam's Needle).

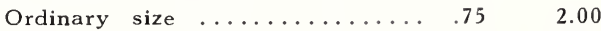

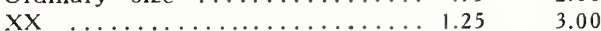

SEND FOR OUR LARGE CATALOG

FOR BARGAINS IN

\section{EVERGREEN TREES, SHRUBS, Etc.}




\section{Reduced Prices of Roses for Fall, 1928}

We are glad to be able to offer our usual list of varieties of Hybrid Perpetuals, Hybrid Teas, and climbing roses at considerably reduced prices and assure our customers as fine stock as we have ever offered. In case customers prefer spring shipment, we will boo's the order at fall prices, provided a deposit of onequarter the amount of the order is made this fall. These roses, grown on the Japanese Multiflora, now considered by rosarians the best stock, are sure to give abundant bloom with very little trouble. Late November shipment for all, except Hybrid Teas, for which we advise early spring north of New York.

A combination of rates may be applied in one order.

Varieties offered at $55 \mathrm{c}, \$ 4.00$ per $10, \$ 35.00$ per 100 .

Varieties offered at $70 \mathrm{c}, \$ 6.00$ per $10, \$ 55.00$ per 100 .

Varieties offered at $\$ 1.00, \$ 9.00$ per ten.

Orders for 50 or more plants, not less than 3 of a name, 100 rate.

Orders for 6 to 50 plants, not less than 3 of a name, 10 rate.

Less than 3 of a name will be sold at single rate.

\section{HYBRID TEA}

Betty. Ruddy gold. 70 cts.

Columbia. Glowing pink. 70 cts.

Eldorado. Beautiful golden yellow. 70 cts.

E. P. H. Kingma. Semi-double. Orange yellow. 70 cts.

Etoile de France. Velvety crimson. $70 \mathrm{cts}$.

Francis Scott Key. Crimson red. 70 cts.

Grange Colombe. Soft ivory white. 70 cts.

Gruss an Teplitz. Brilliant scarlet. 70 cts.

Imperial Potentate. Dark, shining rose pink. 70 cts.

Killarney Queen. Flesh suffused pale pink. 70 cts.

Lady Alice Stanley. Deep coral red. 70 cts.

Lady Ashtown. Soft medium shade of pink .70 cts.

Lady Pirrie. Coppery salmon. 70 cts.

Laurent Carle. Brilliant velvety carmine. 70 cts.

Los Angeles. Pink. 70 cts.

Mme. Butterfly. Pink. 70 cts.

Mme. C. Testout. Pink. 70 cts.

Mme. E. Herriot. Terra cotta. 70 cts.

Mme. Jules Bouche. White. 70 cts.

Miss Lolita Armour. Coral red. 70 cts.

Mrs. Aaron Ward. Indian yellow. $70 \mathrm{cts}$.

Mrs. A. R. Waddell. Orange and salmon. 70 cts.

Mrs. Henry Morse. Contrasting toned pink, yellow glow. 70 cts.

Mrs. W. C. Egan. Deep flesh color with golden glow. $70 \mathrm{cts}$.

Ophelia. Salmon. $70 \mathrm{cts}$

Padre. Coppery scarlet. 70 cts.

Queen of Fragrance. Shell pink. 70 cts.

Radiance. Even shade of pink. $70 \mathrm{cts}$.

Red Radiance. Cerise red. 70 cts.

Rev. F. Page Roberts. Orange gold, shading to saffron yellow. $\$ 1.50$.

Souvenir de Claudius Pernet. Lovely sunflower yellow. $70 \mathrm{cts}$.

Souvenir de Georges Pernet. Brick red. 70 cts.

William F. Dreer. Shell pink, golden yellow at base of petals. 70 cts.

\section{HYBRID PERPETUAL}

Frau Karl Druschki. White. 70 cts. George Arends. Pink. $70 \mathrm{cts}$.

Mrs. John Laing. Pink. 70 cts.

Paul Neyron. Pink. 70 cts.

Prince Camille de Rohan. Crimson. $70 \mathrm{cts}$.

Ulrich Brunner. Scarlet. $70 \mathrm{cts}$.

\section{CLIMBING ROSES}

Prices-2-yr., 55 cts.

American Beauty. Beautiful rose of medium pink. 4-yr., \$1.00.

American Pillar. Single, lovely shade of pink. 4-yr., $\$ 1.00$.

Bess Lovett. Clear, bright red.

Dr. Huey. Deepest crimson-maroon.

Dr. W. Van Fleet. Rich flesh pink.

Dorothy Perkins. Pink.

Emily Gray. Beautiful orange yellow.

Gardenia. Semi-double, yellow.

Hiawatha. Single, crimson.

Lady Gay. Delicate cherry pink.

Mary Wallace. Bright pink, shading to salmon. 4-yr., \$1.00.

Paul's Scarlet. Semi-double, vivid scarlet.

Setigera. Single, pink.

Silver Moon. White.

\section{MISCELIANEOUS ROSES}

Crested Moss. Deep pink. 70 cts.; 3-yr., \$1.00. Edith Cavell. Brill:ant crimson. 4-yr. old, \$1.00.

Ideal. Scarlet. 4-yr. old, \$1.00.

Persian Yellow. Small bright yellow. 75 cts.

Rosa Hugonis. Single yellow. 70 cts.; 4-yr., \$1.50.

Salet Moss. Rose pink. 70 cts.; 3-yr., \$1.00.

\section{RUGOSA}

3-year heavy. 70 cts.

Belle Poitevine. Semi-double, clear pink.

Blanc Double de Coubert. Double white.

New Century. Flesh pink.

Nova Zembla. White.

Rugosa Alba. Single white.

Rugosa Rubra. Rosy crimson.

My dear Mr. Harris :-

Also I want to tell you that all the roses you sent me have bloomed fully, and those you sent to Scotland also.

(Signed) ANNE H. PATTESON

\section{THE ROSEDALE REPUTATION}

IS BUILT SOLIDLY UPON

Thirty Years of Scrupulous Honesty

In the Nursery Business 